\title{
Soil Arthropods in the Douro Demarcated Region Vineyards: General Characteristics and Ecosystem Services Provided
}

\author{
Fátima Gonçalves ${ }^{1,2, *(D)}$, Cristina Carlos ${ }^{1,3}$, Luís Crespo ${ }^{4}$, Vera Zina ${ }^{5}\left(\mathbb{D}\right.$, Amália Oliveira ${ }^{6}$, Juliana Salvação ${ }^{7}$, \\ José Alberto Pereira $^{2}$ (D) and Laura Torres ${ }^{1}$
}

1 Centre for the Research and Technology of Agro-Environmental and Biological Sciences (CITAB), Agronomy Department, University of Trás-os-Montes and Alto Douro, 5000-801 Vila Real, Portugal; cristina.carlos@advid.pt (C.C.); ltorres@utad.pt (L.T.)

2 Centro de Investigação de Montanha (CIMO), Campus de Santa Apolónia, Instituto Politécnico de Bragança, 5300-253 Bragança, Portugal; jpereira@ipb.pt

3 Association for the Development of Viticulture in the Douro Region (ADVID), Center for Excellence in Vine and Wine, Science and Technology Park "Regia Douro Park", 5000-033 Vila Real, Portugal

4 Laboratory for Integrative Biodiversity Research (LIBRe), Finnish Museum of Natural History (LUOMUS), University of Helsinki, P.O. Box 17, 00014 Helsinki, Finland; luiscarloscrespo@gmail.com

5 Forest Research Centre, School of Agriculture, University of Lisbon, Tapada da Ajuda, 1349-017 Lisbon, Portugal; verazina@isa.ulisboa.pt

6 MED—Mediterranean Institute for Agriculture, Environment and Development, University of Évora, Núcleo da Mitra, Apartado 94, 7006-554 Évora, Portugal; amalia.oliveira@gmail.com

7 Independent Forestry and GIS Consultant, Rua da Telheira, ${ }^{\circ} 4$, 5000-471 Vila Real, Portugal; jlsalvacao@hotmail.com

check for updates

Citation: Gonçalves, F.; Carlos, C.; Crespo, L.; Zina, V.; Oliveira, A.; Salvação, J.; Pereira, J.A.; Torres, L. Soil Arthropods in the Douro Demarcated Region Vineyards: General Characteristics and Ecosystem Services Provided. Sustainability 2021, 13, 7837. https://doi.org/10.3390/su13147837

Academic Editor: Susana Santos

Received: 4 June 2021

Accepted: 9 July 2021

Published: 13 July 2021

Publisher's Note: MDPI stays neutral with regard to jurisdictional claims in published maps and institutional affiliations.
* Correspondence: mariafg@utad.pt

\begin{abstract}
Viticulture is one of the oldest and most profitable forms of agriculture; it is also one of the most intensive farming systems. As intensive cultivation threatens the environment, there is increasing interest in the concept of sustainability within the wine industry, as well as new business opportunities, as customers begin to pay more attention to environmental and sustainability issues. Recognizing the key role of soil quality in environmentally and economically sustainable viticulture makes it essential to understand better soil arthropod communities, given their crucial functions in maintaining soil quality and health. The 'Douro Demarcated Region' (DDR) in northern Portugal offers good potential, in regards to biodiversity, due to its significant areas of non-crop habitats. This work aims to compile information on soil arthropod communities (both soil surface and soilliving) collected in the DDR vineyard agroecosystems. A description of the ecosystem services provided by them, as a basis for the development and implementation of sustainable viticulture systems, is also an objective of this work. An important set of soil arthropods necessary for the delivery of vital ecosystem services for viticulture, with particular reference to supporting and regulating services, occurred in this ecosystem. Eight classes were chiefly represented in a sample of about 167,000 arthropod specimens: Arachnida, Chilopoda, Diplopoda, Entognatha, Insecta, Malacostraca, Pauropoda, and Symphyla. The most representative were Entognatha and Insecta in soil-surface arthropods, and Arachnida and Entognatha in soil-living arthropods. The presence of recognized groups as bioindicators in agroecosystems, such as soil quality indicators, is also revealed. This knowledge is expected to contribute to a more efficient and sustainable management of the viticultural ecosystem.
\end{abstract}

Keywords: ecosystem engineers; litter transformers; nutrients; soil-surface arthropods; soil-living arthropods; bioindicators

\section{Introduction}

Most of the biodiversity of agroecosystems lies in the soil, which is the most diverse and complex ecosystem on the planet $[1,2]$. Soil biota plays a critical role in delivering 
a wide range of ecosystem services essential for the sustainable functioning of natural and managed ecosystems $[3,4]$. Soil arthropods may represent as much as $85 \%$ of the soil fauna in terms of species richness [5], play an essential role in maintaining soil quality and health, and provide ecosystem services [6]. The main contribution of soil arthropods to the soil is through the decomposition and humidification of organic matter. However, they may also stimulate the microbial mineralization of soil nutrients through grazing activity [5]. Another significant contribution of arthropods to the soil are their effects on structural properties, namely by soil mixing, developing pores and voids, and soil aggregate formation [5]. Being able to change the physical conditions of the soil by altering its structure and, consequently, its hydrology, as well as its mineral and organic matter composition, arthropods can (directly and indirectly) regulate the availability of resources to other species [5]. Moreover, some arthropods are important predators in the soil surface and litter layer $[7,8]$, contributing to the regulation of pest populations. In contrast, others feed on primary decomposers, contributing to the regulation of the composition and activity of soil organisms [9]. Arthropods are often used to define soil quality since they are involved in many of the soil's ecological functions [6]. Of the various indices used as bioindicators of soil quality, the QBS-ar (Soil Biological Quality-arthropod) index, developed during the past few years [10], links the biodiversity of soil microarthropod communities to the degree of soil vulnerability, and provides information on soil biological quality. Several works have already reported the results of the QBS-ar application to several ecosystems [11-13], including the vineyard agroecosystem $[14,15]$.

However, soil biodiversity (and the ecosystem services it provides) are under threat from a range of natural and manmade factors, including land-use change, agricultural intensification [16,17], and climatic change [16].

In Central and Southern Europe, vineyards are one of the most important agroecosystems [18]. Viticulture is also a vital sector of the agricultural economy of the main wine-producing countries [19]. In the past, viticulture was usually part of a multifunctional agricultural system that produced grapes and provided a diversity of ecosystem services $[18,20]$. Nowadays, vineyards are among the most intensively managed agroecosystems, typically involving the frequent use of phytosanitary products and a marked mechanical imprint on the soil $[19,21]$. These practices lead to a loss of biodiversity and often cause severe impairment of soil functions [22,23], such as pest regulation, soil structure disintegration, organic matter degradation, and soil erosion $[19,20]$.

As a result, the wine-growing sector, as with the agricultural sector in general, is under pressure to turn this intensive post-war agricultural model into a sustainable one [19]. Meanwhile, the term sustainability has already been accepted by a large number of winegrowers and will continue to become even more widely accepted, given the recognition that vineyards can both benefit from, and contribute to, biodiversity conservation and ecosystem service provision, as consumers increasingly appreciate wines produced under environmentally friendly farming practices [24].

The Douro Demarcated Region (DDR), located in northern Portugal and famous for producing Port Wine Denomination of Controlled Origin (DOC), is considered the oldest demarcated and controlled winemaking region in the world, and one of the most important wine regions of the country. In the DDR, vineyards cover an area of $17.5 \%$ (approximately $43,708 \mathrm{ha}$ ) [25]. These vineyards are generally characterized by relatively small sizes, with frequently adjacent areas of non-crop habitats (e.g., woodland remnants, grassy slopes, or terraces with natural vegetation, and dry-stone walls) and soil cover with spontaneous vegetation (which is cut at the beginning of spring) [26].

The Alto Douro Vinhateiro (ADV), a portion of the DDR with about 24,600 ha, has been included in the list of UNESCO World Heritage Sites since 2001 as an evolving and living cultural landscape. About $20 \%$ of this area includes scrubland (or 'mortuaries'), of which one quarter consists of terraces that were abandoned after the devastation of phylloxera, Daktulosphaira vitifoliae, in the late 19th century. These former vineyards are now overrun with wild flora, whose importance for conserving a wide range of biota in 
agricultural landscapes is well known [26]. Currently, the integrity of the ADV prevails, and sustainable solutions are being implemented [27], aiming to promote environmentally friendly farming practices, protect the landscape structures, and ensure the conservation of biodiversity and other natural resources [28].

Unfortunately, as Havlicek [29] indicated, accurate knowledge about soil organisms and their ecosystem functions are still lacking. Often their importance is only shown using global figures and by emphasizing simple facts that are easily understandable by the general public. The emerging interest in sustainability within the wine industry, alongside the recognition of the key role of soil quality [19], gives importance to the existence of a thorough understanding of the communities of soil arthropods due to the critical role they play in maintaining soil quality and health [6]. Thus, understanding soil arthropod communities will help develop management plans for sustainable viticulture.

This work aims to present data on the biodiversity of soil arthropod communities in the DDR vineyards. A description of ecosystem services provided by them is also included. In fact, to our knowledge, this is the first study on the occurrence and ecosystem services provided by soil arthropods associated with vineyard soils. The ultimate goal is that these data, coming from a region of outstanding landscape characteristics, may contribute to a deeper knowledge of vineyard soil arthropods, both soil-surface and soil-living and, thus, to the development and implementation of sustainable viticulture systems.

\section{Methods}

Soil arthropod communities, focusing on both soil-surface and soil-living arthropods, were collected in vineyards from eight farms from the Douro Demarcated Region (although not even in the same vineyards and with the same frequency) (Figure 1, Tables S1 and S2) between 2010 and 2018. Soil-surface arthropods (also referred to as epedaphic arthropods) live and move in the soil surface or in the leaf litter [30]. Soil-living arthropods are the ones that inhabit the voids of the soil mineral horizons beneath the litter layer (euedaphic arthropods) or spend only a portion of their life cycle in the soil (hemiedaphic arthropods) [30].

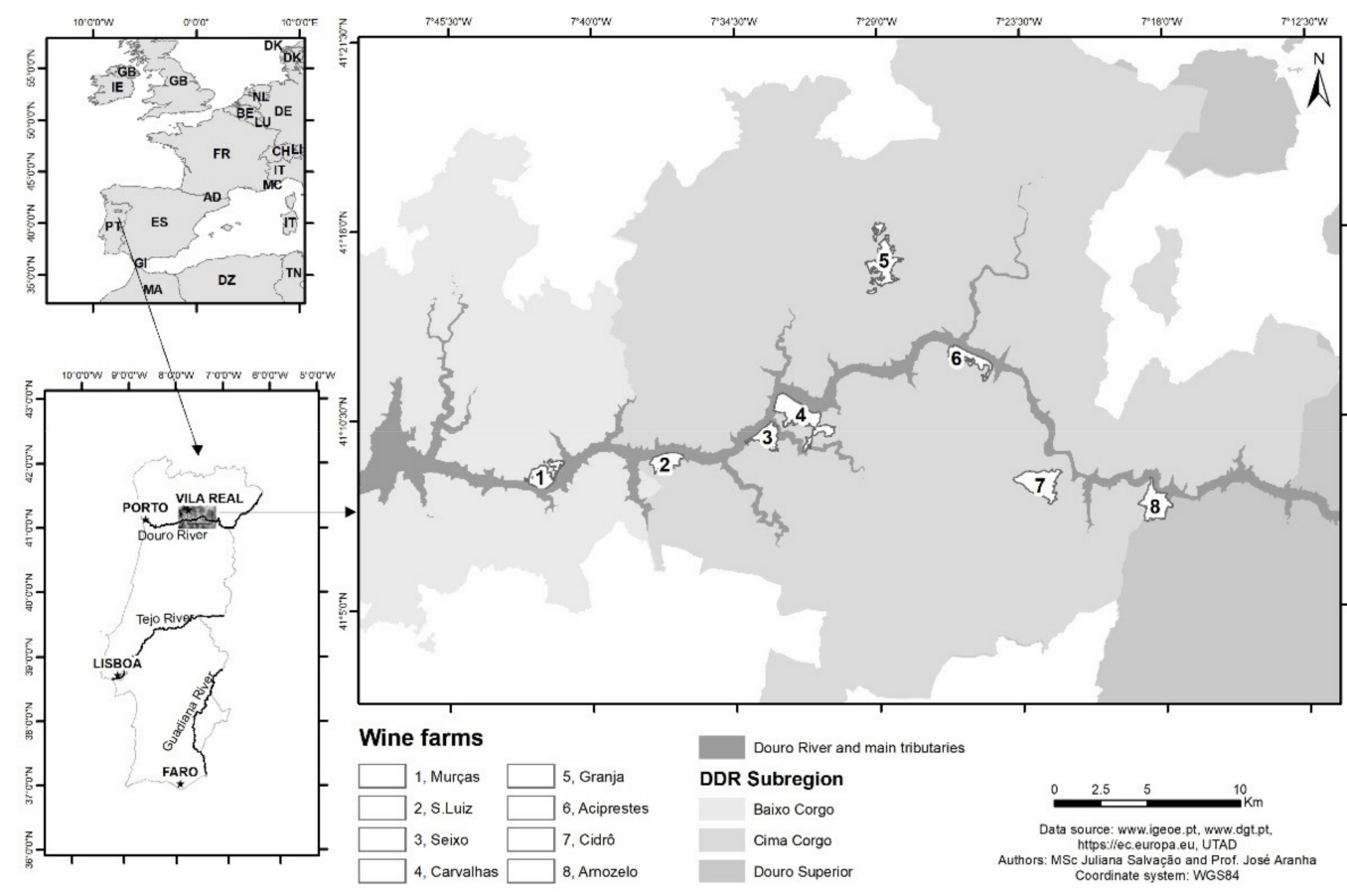

Figure 1. Location of the vineyards where arthropods were collected.

Soil-surface arthropods were sampled in 2010, 2013, 2014, 2015, 2017, and 2018, during the period April to October [14,31] (Table S1). Samplings were done with pitfall traps 
installed in the center of the vineyard inter-rows. Each trap consisted of a plastic cup (16 cm in depth and $9 \mathrm{~cm}$ in diameter) filled with about $150 \mathrm{~mL}$ of a mixture of water and polypropylene-glycol (ratio 3:1). The traps were dug into the ground, uncovered, and kept active for between 24 and $96 \mathrm{~h}$. The arthropod specimens collected were preserved in $70 \%$ ethanol until observation.

Soil-living arthropods were sampled in the spring of 2018 and autumns of 2016 and 2018 (Table S2) when soil moisture ranged between 40 and $80 \%$ of field capacity, since the dry conditions cause vertical migration, immobilization, and aestivation of soil microarthropods [10]. Soil samples were taken using a $10 \mathrm{~cm}$ high and wide spade, and removed with the aid of a hoe; they were then transported to the laboratory in plastic containers with the same dimensions. The arthropods were extracted using a Berlese-Tullgren funnel over seven days. An incandescent lamp $(60 \mathrm{~W})$ was placed $30 \mathrm{~cm}$ above the soil to dry it out gradually and create an inhospitable condition for the arthropods, which moved into the deeper soil layer until they fell into a container with a fixer liquid (mixture of $75 \%$ ethanol and glycerol—ratio 2:1), located under the funnel [10,14].

In both cases, arthropods were counted and sorted into morphospecies and identified by reference to the lowest taxonomic level possible following Triplehorn and Johnson [30]. Taxa described are presented in accordance with the Fauna Europaea systematic order [32].

\section{Results}

\subsection{Abundance and Functional Roles of Soil-Surface Arthropods}

A total of 121,594 soil-surface arthropods belonging to six classes (i.e., Arachnida, Chilopoda, Diplopoda, Entognatha, Insecta, and Malacostraca) were collected (Table 1). Entognatha was found to be the most abundant class $(56.26 \%$ of the total individuals collected), followed by Insecta (34.18\%) and Arachnida (9.17\%). The other classes accounted for less than $1 \%$ of the total soil-surface arthropods: Malacostraca $(0.19 \%)$, Chilopoda $(0.13 \%)$, and Diplopoda (0.07\%) (Table 1$)$.

Table 1. Abundance, relative percentage, and trophic group of soil-surface arthropods collected in the Douro Demarcated Region vineyards, during the period studied (2010-2018) and its importance as bioindicators.

\begin{tabular}{|c|c|c|c|c|}
\hline Taxa & $\mathbf{N}$ & $\%$ & Trophic Group(s) & Bioindicator \\
\hline \multicolumn{5}{|l|}{ Chelicerata } \\
\hline Arachnida & 1149 & 9.169 & & \\
\hline Opiliones & 806 & 0.663 & omn, pred & $\mathrm{Y}$ \\
\hline Pseudoscopiones & 1 & 0.001 & pred & $\mathrm{N}$ \\
\hline Scorpiones & 7 & 0.006 & pred & $\mathrm{N}$ \\
\hline Solifugae & 1 & 0.001 & pred & NA \\
\hline Acari & 5812 & 4.780 & detr, pred & $\mathrm{Y}$ \\
\hline Oribatida & 4054 & 3.334 & detr & \\
\hline Other Acari & 1758 & 1.446 & & \\
\hline Araneae & 4522 & 3.719 & pred & $\mathrm{Y}$ \\
\hline \multicolumn{5}{|l|}{ Crustacea } \\
\hline Malacostraca & 229 & 0.188 & & \\
\hline Amphipoda & 2 & 0.002 & detr & $\mathrm{Y}$ \\
\hline Isopoda & 227 & 0.187 & detr, phyt & Y \\
\hline \multicolumn{5}{|l|}{ Hexapoda } \\
\hline Entognatha & 68406 & 56.258 & & \\
\hline Collembola & 68406 & 56.258 & detr, omn, pred & $\mathrm{Y}$ \\
\hline Insecta & 41563 & 34.182 & & \\
\hline Coleoptera & 5610 & 4.614 & detr, fung, phyt, pred & $\mathrm{Y}$ \\
\hline
\end{tabular}


Table 1. Cont.

\begin{tabular}{|c|c|c|c|c|}
\hline Taxa & $\mathbf{N}$ & $\%$ & Trophic Group(s) & Bioindicator \\
\hline Carabidae & 2075 & 1.706 & omn, phyt, pred & $\mathrm{Y}$ \\
\hline Chrysomelidae & 252 & 0.207 & phyt & $\mathrm{Y}$ \\
\hline Malachiidae & 7 & 0.006 & detr, omn, pred & NA \\
\hline Corylophidae & 26 & 0.021 & fung & NA \\
\hline Latridiidae & 14 & 0.012 & fung & NA \\
\hline Phalacridae & 14 & 0.012 & fung & NA \\
\hline Brentidae + & & & & \\
\hline $\begin{array}{l}\text { Curculion- } \\
\text { idae }\end{array}$ & 234 & 0.192 & detr, phyt & NA \\
\hline Aderidae & 78 & 0.064 & fung & NA \\
\hline Anthicidae & 1321 & 1.086 & detr, pred & NA \\
\hline Meloidae & 3 & 0.002 & phyt, pred & NA \\
\hline Tenebrionidae & 577 & 0.475 & detr, fung & NA \\
\hline Buprestidae & 3 & 0.002 & detr, phyt & NA \\
\hline Elateridae & 139 & 0.114 & omn, phyt, pred & NA \\
\hline Geotrupidae & & & & \\
\hline $\begin{array}{l}\text { + Scarabaei- } \\
\text { dae }\end{array}$ & 141 & 0.116 & copro, detr, phyt & $\mathrm{Y}$ \\
\hline Scydmaenidae & 86 & 0.071 & pred & NA \\
\hline Staphylinidae & 382 & 0.314 & detr, fung, paras, phyt, pred & $\mathrm{Y}$ \\
\hline $\begin{array}{l}\text { Other } \\
\text { Coleoptera }\end{array}$ & 258 & 0.212 & & \\
\hline Dictyoptera & 2 & 0.002 & detr, fung & NA \\
\hline Embioptera & 5 & 0.004 & detr & NA \\
\hline Hemiptera & 597 & 0.491 & phyt, pred & $\mathrm{Y}$ \\
\hline Dictyopharidae & 15 & 0.012 & phyt & NA \\
\hline Cydnidae & 189 & 0.155 & phyt & NA \\
\hline Lygaeidae & 83 & 0.068 & phyt, pred & NA \\
\hline Pentatomidae & 16 & 0.013 & phyt, pred, omn & NA \\
\hline Rhopalidae & 288 & 0.237 & phyt & NA \\
\hline Scutelleridae & 6 & 0.005 & phyt & NA \\
\hline Hymenoptera & 34869 & 28.677 & detr, omn, paras, phyt, pred & $\mathrm{Y}$ \\
\hline Formicidae & 34757 & 28.584 & detr, omn, phyt, pred, & $\mathrm{Y}$ \\
\hline Mutillidae & 89 & 0.073 & paras, pred & NA \\
\hline Dryinidae & 23 & 0.019 & paras, pred & NA \\
\hline Orthoptera & 480 & 0.395 & detr, omn, phyt, pred & $\mathrm{Y}$ \\
\hline \multicolumn{5}{|l|}{ Myriapoda } \\
\hline Chilopoda & 161 & 0.132 & pred & $\mathrm{Y}$ \\
\hline Diplopoda & 86 & 0.071 & detr, omn, pred & Y \\
\hline Total & 121594 & 100.000 & & \\
\hline
\end{tabular}

\subsection{Abundance and Functional Roles of Soil-Living Arthropods}

Concerning to soil-living arthropods, a total of 45,052 specimens belonging to eight classes (i.e., Arachnida, Chilopoda, Diplopoda, Entognatha, Insecta, Malacostraca, Pauropoda, and Symphyla) were collected (Table 2). In this community, Arachnida (45.38\%) and Entognatha ( $42.45 \%$ ) were found to be the most abundant classes, followed by Insecta $(10.83 \%)$, Symphyla $(0.67 \%)$, and Chilopoda ( $0.52 \%)$. Diplopoda, Malacostraca, and Pauropoda accounted for less than $0.1 \%$ of total soil-living arthropods (Table 2). 
Table 2. Abundance, relative percentage, and trophic group of soil-living arthropods collected in the Douro Demarcated Region vineyards, during the period studied (2016 and 2018) and its importance as bioindicators.

\begin{tabular}{|c|c|c|c|c|}
\hline Taxa & $\mathbf{N}$ & $\%$ & Trophic Group(s) & Bioindicator \\
\hline \multicolumn{5}{|l|}{ Chelicerata } \\
\hline Arachnida & 20444 & 45.381 & & \\
\hline Opiliones & 2 & 0.004 & omn, pred & $\mathrm{Y}$ \\
\hline Pseudoscopiones & 42 & 0.093 & pred & $\mathrm{N}$ \\
\hline Acari & 20331 & 45.130 & detr, pred & $\mathrm{Y}$ \\
\hline Araneae & 62 & 0.138 & pred & $\mathrm{Y}$ \\
\hline Palpigradi & 7 & 0.016 & bact & NA \\
\hline \multicolumn{5}{|l|}{ Crustacea } \\
\hline Malacostraca & 21 & 0.047 & & \\
\hline Isopoda & 21 & 0.047 & detr, phyt & $\mathrm{Y}$ \\
\hline \multicolumn{5}{|l|}{ Hexapoda } \\
\hline Entognatha & 19126 & 42.453 & & \\
\hline Collembola & 18737 & 41.590 & detr, omn, pred & $\mathrm{Y}$ \\
\hline Diplura & 345 & 0.766 & microb, pred & Y \\
\hline Protura & 44 & 0.098 & fung & $\mathrm{Y}$ \\
\hline Insecta & 4881 & 10.834 & & \\
\hline $\begin{array}{l}\text { Coleoptera (adults and } \\
\text { larvae) }\end{array}$ & 813 & 1.805 & detr, fung, phyt, pred & $\mathrm{Y}$ \\
\hline Dictyoptera (Isoptera) & 47 & 0.104 & detr, fung & NA \\
\hline Diptera (larvae) & 303 & 0.673 & detr, paras, phyt, pred & Y \\
\hline Embioptera & 13 & 0.029 & detr $\Gamma$ & NA \\
\hline Hemiptera & 126 & 0.280 & phyt, pred & $\mathrm{Y}$ \\
\hline Hymenoptera (Formicidae) & 3282 & 7.285 & detr, omn, phyt, pred & $\mathrm{Y}$ \\
\hline Lepidoptera (larvae) & 254 & 0.564 & phyt, pred & $\mathrm{Y}$ \\
\hline Neuroptera (larvae) & 5 & 0.011 & detr, omn phyt, pred & Y \\
\hline Thysanoptera & 38 & 0.084 & fung, omn, phyt, pred & Y \\
\hline \multicolumn{5}{|l|}{ Myriapoda } \\
\hline Chilopoda & 234 & 0.519 & pred & Y \\
\hline Diplopoda & 31 & 0.069 & detr, omn, pred & $\mathrm{Y}$ \\
\hline Pauropoda & 13 & 0.029 & detr, microb & Y \\
\hline Symphyla & 301 & 0.668 & detr, phyt, pred & NA \\
\hline Total & 45052 & 100.000 & & \\
\hline
\end{tabular}

\section{Review of the Systematic Groups and Their Functionality}

\subsection{Chelicerata Arachnida}

\subsubsection{Dromopoda}

Opiliones (Harvestmen)

Opiliones (Figure 2e) live mostly on the soil surface, and only a few species penetrate the upper layers of litter. Although some species require a specific diet (almost exclusively on terrestrial snails and slugs) [33], most species are omnivorous, feeding on a wide variety of other arthropods and invertebrates, as well as fungi and other organic debris, and juices from soft berries and fruits [6,9]. As predators, most species seem to rely on an ambush strategy or, more rarely, active hunting [33]. The soil-dwelling species move slowly and have a smaller body with significantly shorter and stronger legs than those living above the ground [6]. 


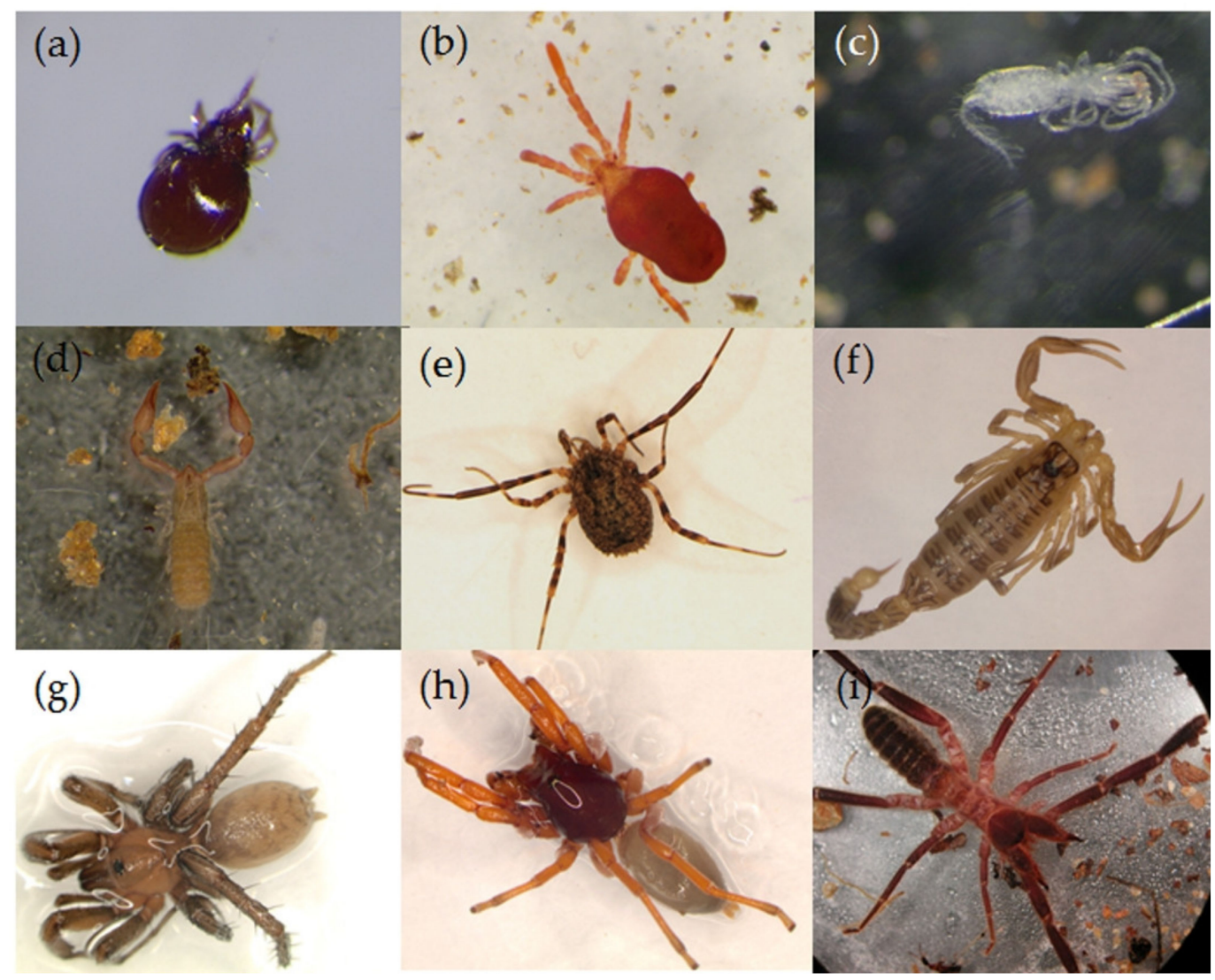

Figure 2. Arachnids commonly found in vineyard soils from the Douro Demarcated Region: Acari (Oribatida (a) and Prostigmata (b), Palpigradi (c), Pseudoscorpiones (d), Opiliones (e), Scorpiones, Buthus ibericus (f), Araneae Gnaphosidae (g), and Dysderidae (h), and Solifugae, Gluvia dorsalis (i).

They are excellent predictors of environmental quality, given their rapid responses to habitat change and fragmentation [34]. As predators, harvestman reflects changes in the food web of the leaf litter habitat [35]. They are good indicators of high-quality habitats, but not during the early stages of ecosystem recovery [35], because most species are slow to recolonize disturbed areas [36]. However, the problematic identification and taxonomy of this group is a disadvantage for their use as ecological indicators [6]. In the DDR vineyard soils, the Opiliones represented about $0.7 \%$ of the total soil-surface arthropods collected and less than $0.01 \%$ of the soil-living arthropods (Tables 1 and 2).

\section{Pseudoscorpiones (False Scorpions)}

Pseudoscorpiones (Figure 2d) occur in the soil, in leaf litter, and under the bark of trees and logs [37] in generally stable environments [6]. They are mostly predators of springtails, mites, and other smaller invertebrates that they can catch [37]. Even Pseudoscorpiones have been suggested as soil quality indicators, they are generally too scarce and too difficult to identify to be useful for indicating diversity [35]. In the DDR vineyard soils, Pseudoscorpiones represented less than $0.01 \%$ of the total soil-surface and about $0.1 \%$ of the soil-living arthropods collected (Tables 1 and 2).

\section{Scorpiones (Scorpions)}

Scorpiones (Figure 2f) are opportunistic predators mostly of soft-bodied insects and other arachnids [38]. They have nocturnal habits, while during the day, they remain mainly on the surface of the soil, hidden under rocks, in crevices, or in burrows, from where they set out after sunset to hunt and feed [38]. Because of their low diversity and incidence in most geographical areas, scorpions have limited potential as bioindicators [35]. In the DDR 
vineyard soils, Scorpiones consisted of less than $0.01 \%$ of the total soil-surface arthropods collected (Table 1), and were represented by Buthus ibericus Lourenço and Vachon.

\section{Solifugae (Camel Spiders)}

Solifugae (Figure 2i) are one of the most important predators of arid environments [38]. They are voracious predators of a variety of soil-surface arthropods, principally ants and spiders, which are captured only during the first hours of the night [39]; they live on the soil surface, being cursorial predators (i.e., explicitly adapted to run), capable of covering considerable distances in search of food [40]. They have a preference for habitats of a semidesert character $[39,41]$, particularly sand substrate, rocks, and low and sparse vegetation cover [39]. No literature was found on the use of this group as bioindicator; however, like the Pseudoscorpiones and Scorpiones, due to their low incidence it is admissible that they have limited potential as bioindicators. In the DDR, Solifugae consisted of less than $0.01 \%$ of the total soil-surface arthropods collected (Table 1 ) and were represented by Gluvia dorsalis (Latreille), an endemic species to the Iberian Peninsula, whose protection is recommended; in Catalonia (Spain), this species has been protected by legislation since 1992 [41]. G. dorsalis is mostly limited to areas of the Iberian Peninsula with scarce summer rain [39].

\subsubsection{Micrura}

Acari (Mites)

Acari are one of the most abundant, diverse, and successful soil-inhabiting arthropods [5,9]. They have a diversity of lifestyles and eating behavior and consequently perform different functions in the soil.

There are three main groups of soil and leaf litter mites: Oribatida, Mesostigmata, and Prostigmata. Oribatida (Figure 2a), which are the world's most numerous arthropods living in the soil [42], are an important component of soil detritivores, by feeding on a variety of leaf litter material, including bacteria and yeast, algae, fungi, and rotting wood [42]. They live in dense clusters in the decomposing litter within the upper soil layers. Their occurrence depends on the thickness of the soil organic horizons, the quality of the litter, and $\mathrm{pH}$ values (evidently, acidified soils, and a recalcitrant litter material improve the dominance of oribatids) [7]. Some Mesostigmata are predators, eating small invertebrates, such as springtails and other mites; others are parasitic on vertebrates or invertebrates [43]. Prostigmata (Figure $2 b$ ) have highly variable feeding habits, including nematodes, other smaller arthropods and algae, fungi, and bacteria; some live on other animals as parasites [37]. Many species of predatory mites have adapted to attack the different prey types living in the different soil horizons [7].

It is believed that the distribution in the soil of Oribatida tends to be more aggregated than that of the predatory mites, which is more uniform due to the behavior of some predators that try to increase the spectrum of their prey by being more mobile [7].

Because mites play essential roles in key biological processes, they are suitable organisms to be used as bioindicators of the status of the ecosystem. They also reflect changes in soil quality, especially those due to land use practices and pollution [9], and are used to monitor the progress of habitat management [44]. They are also sensitive to toxins and have a role in pollution indication [45]. Oribatida are common in barely disturbed soils and with a high organic content [46]. Thus, the abundance, species composition, and diversity of oribatids in a particular habitat are good indicators of soil health [42].

In the DDR vineyard soils, Acari represented $4.8 \%$ of the total soil surface, and $45.1 \%$ of the total soil-living arthropods collected (Tables 1 and 2).

Araneae (Spiders)

Araneae (Figure 2g,h) are ubiquitous predators in terrestrial ecosystems that feed primarily on insects, although they also consume other arthropods, including other spiders [47]. Spiders are most abundant near the soil surface and within the litter [7]. 
Despite their almost uniquely predatory habits, spiders do not constitute a homogeneous functional group. They reveal significant behavioral diversity concerning their different predation strategies, dispersal modes, and great ability to resist adverse ecological conditions [48]. The soil is often used as a hunting ground for spiders, in which they use different methods to capture prey. Some spiders are active hunters that pursue their prey; others instead weave webs to capture prey [49]. Many others inject venom into their prey to kill them quickly, whereas others first use silk wrappings to immobilize them [49]. Larger species are mostly found in the soil surface or in the litter, often hiding or sheltering under rocks and fallen wood. Some species burrow holes into the soil from which they catch their prey. There are also a significant number of small species, which inhabit soil pores and cavities [9].

Although it is assumed that spiders are usually generalists, being able to catch a wide variety of prey types [50], some species specialize in hunting within a particular prey group. Pekár et al. [51] reported six categories of stenophagy among spiders: araneophagy, crustaceophagy, dipterophagy, lepidopterophagy, myrmecophagy, and termitophagy. In addition, some species of spiders also mimic ants to deceive primarily their predators [52]; this is considered a case of Batesian mimicry [53], where a palatable mimic spider escapes from predators, which have experienced unpalatable ants [54].

Since spiders are diverse, and some families are conspicuous and relatively easy to identify, they have been used as indicators of specific habitat characteristics or habitat change, with the potential to be used as indicators of habitat management and habitat restoration [35]. Spiders respond to environmental changes and are highly sensitive to even small changes in habitat structure (mainly related to vegetation) and microclimatic factors [6]. Being among the top macroinvertebrate predators, the amount of prey ingested by spiders depends on the total quantity of potential prey. Thus, a change in spider composition and dominance can indicate the biological quality of the habitat [6].

Spiders have also been used as bioindicators of disturbances caused by agrochemicals, such as pesticides, which might have negative lethal and sublethal effects on behavior and physiological traits, such as feeding, locomotion, web building, reproduction, and development [55]. Moreover, spiders accumulate pollutants and pesticides, and so they can be used as ecological accumulators to indicate environmental toxin levels [35,49]. The accumulation of pollutants, such as heavy metal concentrations, can be identified by a field evaluation of ecosystem contaminations. Since spiders are part of the diet of reptiles, amphibia, birds, and small mammals, they can also give valuable information on heavy metal concentrations that could be toxic to vertebrates [48].

In the DDR vineyard soils, Araneae represented $3.7 \%$ of the total soil-surface and $0.1 \%$ of the soil-living arthropods collected (Tables 1 and 2). It was possible to identify 23 families, 66 genera, and 61 species (Table S6). The most abundant were Lycosidae, Gnaphosidae, Zodariidae, Thomisidae, and Agelenidae (Table S3). Lycosidae was also the most abundant family found in vineyards of Austria [56], Romania [57], and Spain [58]. According to Branco et al. [59], nine species are endemic to the Iberian Peninsula, i.e., Eratigena bucculenta, E. montigena, and Tegenaria ramblae from Agelenidae; Zodarion alacre and Zodarion duriense from Zodariidae; Castianeira badia from Corinnidae; Nemesia athiasi from Nemesiidae, Oecobius machadoi from Oecobiidae and Zelotes fuzeta from Gnaphosidae) (Table S4). Following Cardoso et al. [60], it was possible to group the Araneae from DDR vineyard soils into eight guilds: ground hunters, specialists (S), other hunters, sheet web weavers, ambush hunters, space web weavers, sensing web weavers, and orb-web weavers (Table S4). Hunting spiders were found to be the most abundant guilds in the soil surface, which is in accordance with Eisenbeis [7], who stated that the non-web building cursorial spiders, which actively pursue their prey, are more abundant in the top litter layer in contrast with the web-spinning families that are more abundant in the lower litter layers. The specialist spiders found in the DDR vineyard soils belong to the Zodariidae and Dysderidae families. In Zodariidae, Zodarion is considered to be adapted to hunting ants [51,61], presenting nutritional limitations if non-ant prey is used 
as food [62]; for instance, Z. styliferum hunt predominantly on Messor and Lasius ants [63]. Some species from Dysdera in Dysderidae are oniscophagous specialists (feeding preferably on woodlice (Isopoda)); this is because such species have modified chelicerae, which can insert themselves into the heavy armor of woodlice [64].

\section{Palpigradi (Microwhip Scorpions)}

Palpigradi (Figure 2c) dwell in moist and stable habitats [65]. They are very common in tropical soils, while in Europe, they are rare and usually associated with caves [9]. As with most arachnids, they were previously believed to be predators. Recently, however, it has been shown that the European cave-dwelling species Eukoenenia spelaea is specialized in feeding on cyanobacteria rather than invertebrates [65]. No literature was found on the use of this group as bioindicator; however, due to their low incidence in soils it is admissible that they have limited potential as bioindicators. In the DDR vineyard soils, Palpigradi represented about $0.02 \%$ of the total soil-living arthropods collected (Table 2).

\subsection{Crustacea-Malacostraca}

\subsubsection{Amphipoda (Terrestrial Amphipods)}

Terrestrial amphipod species (Figure 3a) from the family Talitridae feed exclusively on decaying vegetation $[66,67]$. In general, they live in litter, under logs and rocks, in unlined burrows in the soil, which they build themselves, or in the burrows of other species [67]. They move freely, mainly at night [66], and may climb onto the vegetation (crop canopies and ground cover) to reach dead leaves above the ground [67]. They cannot survive in dry habitats, being restricted to relatively moist environments [67]. Desiccation and osmotic stress caused by submergence in rainwater are referred to as the main mortality factors [66]. Some species have been used in biomonitoring of trace metal [68]. In the DDR vineyard soils, Amphipoda represented less than $0.01 \%$ of the total soil-surface arthropods collected (Table 1).

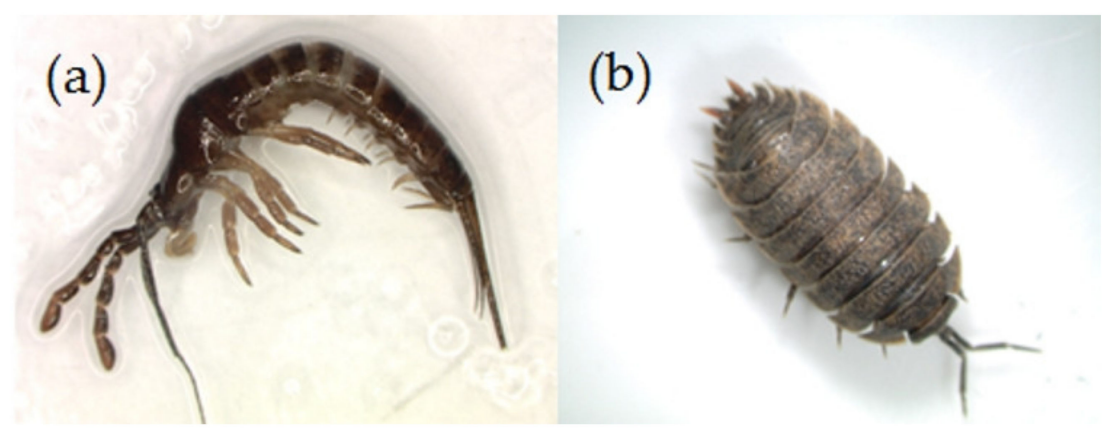

Figure 3. Terrestrial amphipod (a) and terrestrial isopod (b) common in vineyard soils from the Douro Demarcated Region.

\subsubsection{Isopoda (Terrestrial Isopods)}

Terrestrial isopod species (Figure $3 b$ ) from the suborder Oniscidea are most common in environments with a high degree of humidity, moisture being an important limiting factor in their distribution [69]. They are usually found under stones, tree logs, in the leaf litter of woods, among grasses in meadows, and even on bushes and in the tree canopy, being active mainly during the night to prevent desiccation [9]. In general, terrestrial isopods are scavengers eating mostly dead or decaying plant material [37], though they also eat dead animal remains and dung and occasionally ingest bacteria, fungi, and living plants. Some isopod species have been observed feeding on green living tissues of several plants and seeds of weeds or crop plants [70]. Terrestrial isopods are very good ecological and biogeographical indicators because most of them are closely linked to the soil; they have a low dispersal ability and are often abundant and easily recorded [9]. They are potentially valuable indicators of the environmental quality and impact of agricultural practices [70,71]. They are also indicated as useful for the risk assessment of pesticides [72] and other 
toxicological elements, such as heavy metals [73-75], in the terrestrial environment. In the DDR vineyard soils, Isopoda represented about $0.2 \%$ of the total soil-surface and $0.05 \%$ of the soil-living arthropods collected.

\subsection{Hexapoda Entognatha}

\subsubsection{Collembola (Springtails)}

Collembola (Figure $4 \mathrm{a}-\mathrm{c}$ ) are common in the soil, leaf litter, and other decaying dead organic matter [76,77]. Together with Acari, Collembola make up the most abundant arthropods in the soil and leaf litter [37].

Omnivory is probably their prevailing feeding strategy [78]. Although they are usually highly specialized feeders on soil microbiota (fungi, bacteria, actinomycetes, algae) $[79,80]$, Collembola also feeds on plant litter, plant tissues [79], and animal feces [81]. Some are occasionally or primarily carnivores feeding on nematodes or other Collembola and their eggs [80,82] and eggs of other arthropods [83].

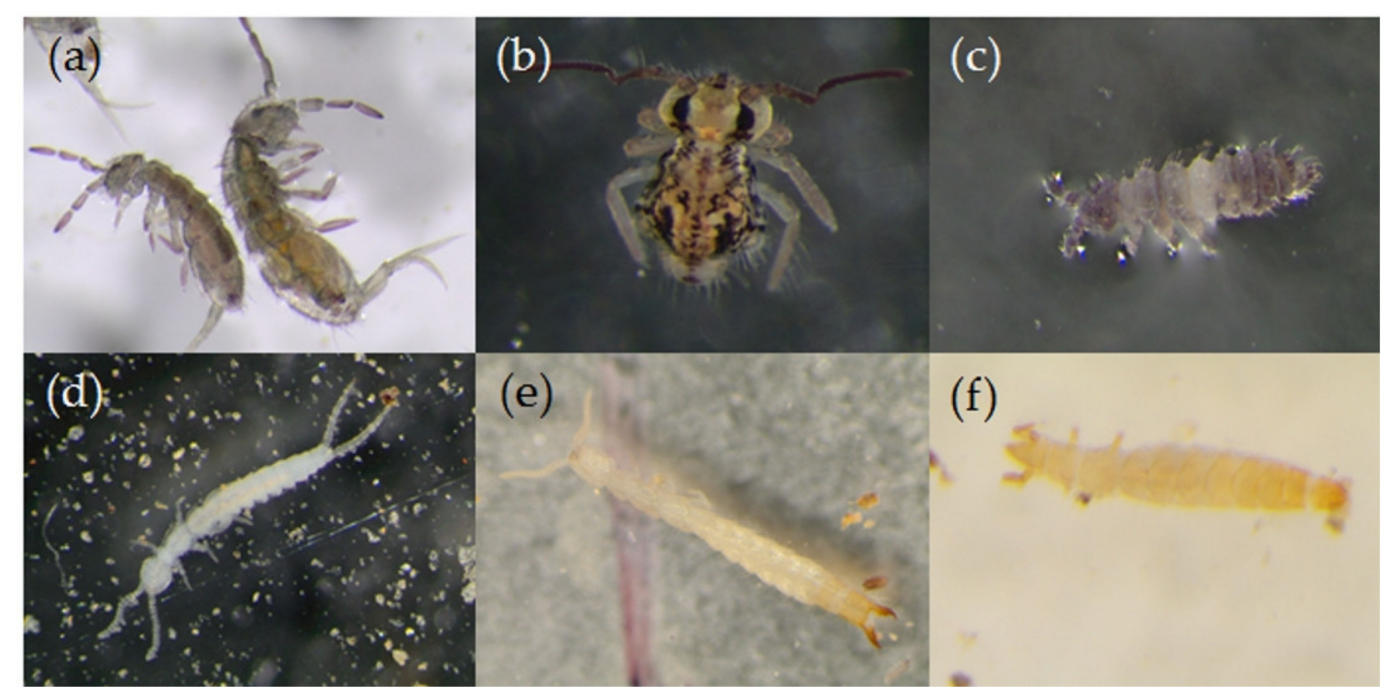

Figure 4. Entognatha common in vineyard soils from the Douro Demarcated Region: Colembolla with different morphological forms (a-c), Diplura Campodeoidea superfamily with filamentous cerci (d) and Japygoidea superfamily with cerci, with a pair of pincers or forceps (e) and Protura (f).

Some Collembola live on the surface of the leaf litter and others deeper down in the soil. Morphological and physiological differences exist between soil-living and soil-surface species. These differences involve the shape and size of the body, which is more slender and smaller in soil-living species, the appendages (legs, antennas, furca), as well as eyes and bristles, which are more reduced, and the pigmentation, which is also weaker in the soil-living species [7,9].

Collembola are able to move vertically in the soil as well as between the soil surface and the vegetation layer, although true edaphic species can only leave the soil under the shelter of darkness and when the humidity is high [7]. The dynamics of their communities are therefore closely related to environmental conditions [84]. Temperature and humidity are determinant factors in the reproduction rate, development, and survival of Collembola and responsible for their vertical distribution in the soil [85], especially during dry seasons when they move to deeper soil layers [86,87] or become dormant or quiescent [77].

Because Collembola respond to a variety of environmental and ecological factors, and because they are an integral part of soil ecosystems, present in high numbers and diversity, they can be beneficial organisms, to be used as bioindicators of changes in soil quality, especially those due to land use intensification [88,89], soil acidification, and nitrogen supply [79], metal contaminations [90,91], microplastic pollution [92], pesticide use [93,94], air pollution [95], and the effects of climate change [88,89]. 
In the DDR vineyard soils, Collembola represented about $56.3 \%$ of the total soil-surface and $41.6 \%$ of the soil-living arthropods collected (Tables 1 and 2).

\subsubsection{Diplura (Diplurans)}

Diplura (Figure $4 \mathrm{~d}, \mathrm{e})$ usually live in the deeper layers of the soil or the litter layer, preferring soils with relatively high and stable moisture content due to their extreme susceptibility to desiccation [7]. Diplura depend on high humidity and moderate temperatures and are presumably very sensitive to anthropogenic pressures and climate change [96]

The superfamilies in this order have different feeding habits: Campodeoidea feed on algae, bacteria, fungi, small fragments of litter, and dead soil animals [7,97], although they also feed on small larvae of insects, mainly Diptera [97]. Japygoidea and Projapygoidea are hunters, feeding on small arthropods, such as collembolans and mites, as well as nematodes and enchytraeids $[9,97]$. Japygoidea use their forceps to grasp their victims $[7,98]$ while Projapygoidea have been observed using their cercal silk secretions to capture prey [98].

In the DDR vineyard soils, Diplura represented about $0.8 \%$ of the total soil-living arthropods collected (Table 2).

\subsubsection{Protura (Proturans)}

Protura (Figure 4f) are found almost universally, where there is decaying organic matter and sufficient moisture, essentially in the first centimeters of the soil $[99,100]$. Vegetation and the physicochemical characteristics of the soils may also influence their population density [100].

Although previous authors have assumed that Protura have a predatory diet, or subsequently, a detritivorous diet, feeding on decaying plant material [99], recent studies have shown that they are specialized mycorrhizal feeders [101,102], feeding on mycorrhizal hyphae by sucking up hyphal cytoplasm [102].

Protura may potentially serve as indicators for several ecological conditions in the soil. Thus, their abundance and richness, as well as community composition, may reflect an association with fungal communities and the presence of mycorrhiza development [101,102]; they can also reflect the level of habitat disturbance due to actions, such as urbanization $[100,103,104]$ and agrochemical presence or repeated mechanical disturbance [103]. In very disturbed and degraded soils, Protura either can be completely absent [82] or only represented by widely distributed species [100].

In the DDR vineyard soils, Protura represented about $0.1 \%$ of the total soil-living arthropods collected (Table 2).

\subsection{Hexapoda Insecta \\ 4.4.1. Coleoptera (Beetles)}

Coleoptera, being the largest insect order, have great importance in agricultural and forest ecosystems. They feed on all sorts of plant and animal materials. Some species are phytophagous, while others are predators, detritivorous, or fungivorous [105]. Given this, they can be used to detect many kinds of alteration in the environment [106], such as pollution and post-fire recovery [6]. In the DDR vineyard soils, Coleoptera represented about $4.6 \%$ of the total soil-surface, and $1.8 \%$ of the soil-living arthropods collected (Tables 1 and 2). Coleoptera from the surface were included in 18 families from 10 super-families, namely: Carabidae (Caraboidea), Chrysomelidae (Chrysomeloidea), Malachiidae (Cleroidea), Corylophidae, Latridiidae, Phalacridae (Cucujoidea), Brentidae, Curculionidae (Curculionoidea), Aderidae, Anthicidae, Meloidae, Tenebrionidae (Tenebrionoidea), Buprestidae (Buprestoidea), Elateridae (Elateroidea), Geotrupidae, Scarabaeidae (Scarabaeoidea), Scydmaenidae, and Staphylinidae (Staphylinoidea).

\section{Carabidae (Ground Beetles)}

Carabidae (Figure 5a) are largely confined to the ground, although some species also climb into trees and shrubs in search of prey [107]. Most are nocturnal and hide during the 
day in leaf litter, or under logs, stones, and bark [105]. Their activity is mainly affected by temperature, light intensity, humidity, food condition, and presence of competitors [107], soil type, $\mathrm{pH}$, and vegetation (ground and crop cover) [108]. Carabids are mostly predators, both as larvae and adults, of invertebrates, such as insects, spiders, slugs, and snails [109]. Nevertheless, many species can be classified as phytophagous (feeding on seeds, pollen, sprouts of different plants) or omnivorous [109]. Seed feeding occurs in many species, including polyphagous ones that prefer animal prey [110]; however, true seed feeders, i.e., where seeds are central to the species' food budget, occur only in the tribes Zabrini and Harpalini [110]. Some Carabidae predators specialize in hunting ants, and have undergone interesting behavioral and morphological adaptations (e.g., chemical mimicry to reduce the risk of being attacked by their hosts) [110].

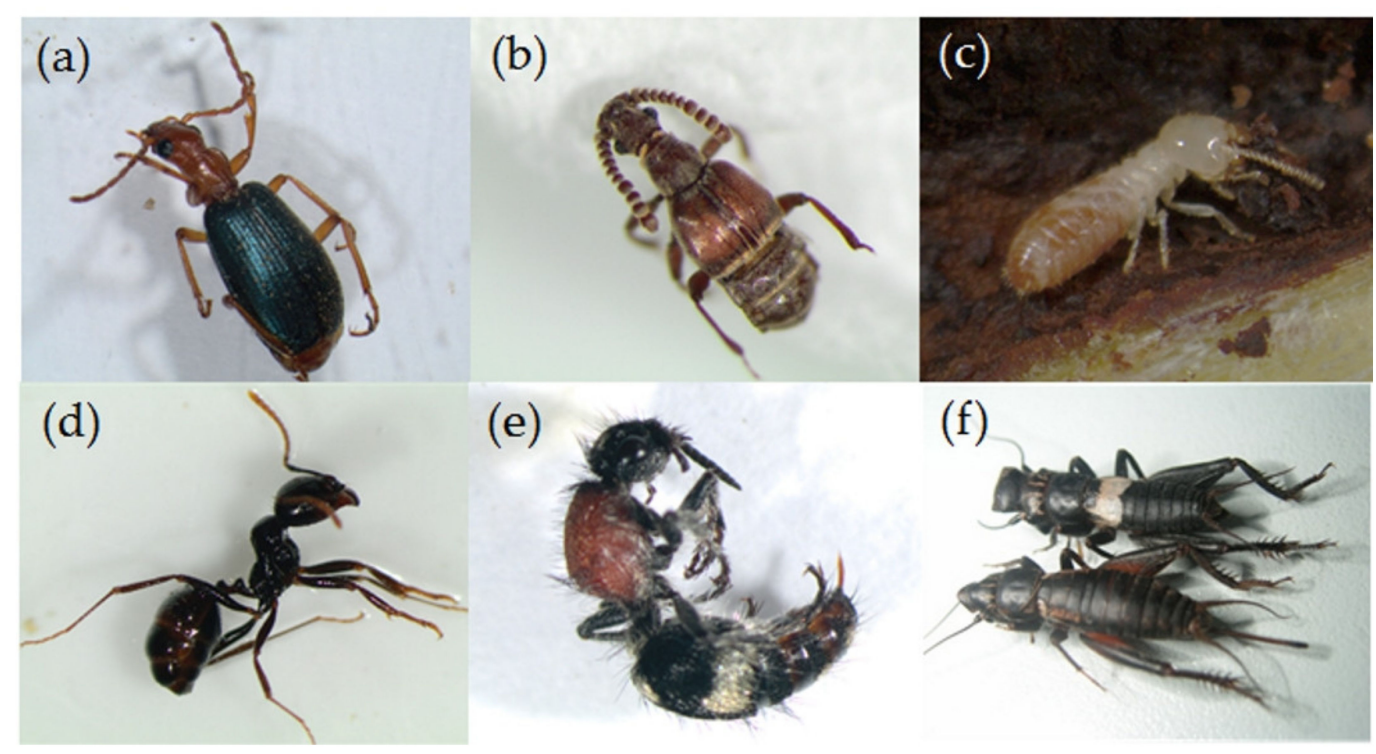

Figure 5. Insects common in vineyard soils from the Douro Demarcated Region: Coleoptera Carabidae (a) and Staphylinidae (b), Dictyoptera (Isoptera) (c), Hymenoptera Formicidae, Messor barbarous (d), and Mutilidae (e), Orthoptera Sciobia lusitanica (f).

Carabids have been widely and successfully used as indicators of environmental and habitat change, such as landscape fragmentation [111], soil management practices, pesticide and fertilizer applications [108], and heavy metal pollution [112]. As reviewed by Rainio and Niemelä [113], landscape fragmentation causes changes in size and shape of the fragment, degree of spatiotemporal isolation, degree of habitat connectivity in the landscape, and edge effects, which have important effects on carabid assemblages such as species composition, abundance in some species (increasing or decreasing), specialist species decline, and increases in open habitat species. Although some revisions have indicated that carabids are relatively poor heavy metal accumulators [114,115], recent studies have stated that they can be used effectively as a naturally available pollution indicator $[106,112]$ and that they can even be used as entomoremediators, helping decontaminate soils badly polluted by metals via sequestering metals in their tissues [112].

In the DDR vineyard soils, it was possible to identify 12 subfamilies, 34 genera, and 55 species of Carabidae (Table S4), included in three trophic groups (predators, omnivores, and phytophagous) (Table S4). The most collected species were Steropus (Sterocorax) ebenus, Calathus (Neocalathus) granatensis, Calathus (Neocalathus) mollis, and Brachinus (Brachynidius) variventris. According to Jiménez-Valverde and Ortuño [116], four species, i.e., Licinus (Licinus) aequatus, Leistus (Leistus) oopterus, C. granatensis, Platyderus (Platyderus) lusitanicus are endemic to the Iberian Peninsula (Table S4). 


\section{Chrysomelidae (Leaf Beetles)}

Most adult Chrysomelidae are leaf feeders, with some species specialize in a wide variety of seeds and a few species being associated with pollen [117]. However, the feeding regime is diverse since they may feed externally on the leaf tissue or the roots, within leaves, stems, or roots, often as miners, or within seeds $[105,117]$. Some species are agricultural pests, causing direct damage to various parts of the plant, mainly through reducing the leaf area; they sometimes also cause indirect damage via the transmission of plant viruses [117]. They are also considered selective phytophagous insects, depending on a set of plants to survive and persist in natural habitats [6]. Such characteristic makes this family a good bioindicator, as they are expected to respond to environmental alterations such as anthropogenic disturbance [6].

In vineyards, the chrysomelid species Altica ampelophaga Guérin-Méneville, also known as "vine leaf beetle" is considered a minor pest. This insect pupates in the soil, and in the spring, larvae and adults can cause significant defoliation by feeding on the newly sprouting vines. In summer, they feed on mature leaves, often resulting in the appearance of lace-like areas [117].

\section{Malachiidae (Soft-Winged Flower Beetles)}

Adult Malachiidae are commonly found on flowers, where they feed on pollen and on flower-visiting insects [118,119]. Larvae are located in the soil, leaf litter, and under the bark as well as dead wood and in stems of plants [118], being in general detritivorous feeding on dead animal material, or predators feeding on arthropod eggs, larvae, and soft-bodied adults [119].

\section{Corylophidae (Minute Fungus Beetles)}

Both adults and larvae of Corylophidae feed on fungi, in most cases on spores of deuteromycete or ascomycete fungi, occurring in a variety of microhabitats, including leaf and bark surfaces, under bark, in leaf litter, and bird nests [120].

\section{Latridiidae (Minute Brown Scavenger Beetles)}

Both larvae and adults of Latridiidae are found in moldy material and debris, where they feed predominantly on fungal fruiting bodies [121], predominantly on the spores and conidia of Ascomycetes, Deuteromycetes, and Zygomycetes [122]; sometimes they are also found on flowers [105].

\section{Phalacridae (Shining Flower Beetles)}

Phalacridae are commonly found on dead vegetation and flowers [123]. Adults and larvae feed on fungi and pollen of Asteraceae [123].

\section{Brentidae (Straight-Snouted Weevils)}

Within the Brentidae, the adults of the subfamily Apioninae, which were collected in DDR vineyards, feed on living plant tissues, including all green parts and fruits. Larvae also feed on different plant parts, including stems, roots, inflorescences, fruits, seeds, and tissues, forming gall-like structures [124].

\section{Curculionidae (Snout Beetles)}

Concerning Curculionidae, almost all members of this family feed on both living and dead plants, and many are serious pests; almost every part of a plant may be attacked [105]. In vineyards, the Curculionidae Otiorhynchus sulcatus Fabricius, also known as "black vine weevil", is considered a minor pest. The adults are nocturnal and feed on buds and leaves, causing mostly cosmetic damage, whereas the larvae are ground-dwelling and feed on the root system, which may result in reduced vigor and subsequent death of the plants [125]. 


\section{Aderidae (Antlike Leaf Beetles)}

As adults, Aderidae are frequently found resting on the undersides of leaves of various deciduous shrubs and trees. Larvae are found in rotten wood, wood mold, leaf litter, hollows of old trees, under bark and possibly feeding on deuteromycete or ascomycete fungi [126].

\section{Anthicidae (Antlike Flower Beetles)}

Anthicidae are often found under stones and logs and in debris in the soil or, during the day, climbing on flowers and other vegetation [105,127]. Adults of those species that live on the ground are thought to be detritivorous and opportunistic predators, feeding on organic debris and small or weakened invertebrates [127]. In vegetation, they can feed on small invertebrates, pollen and fungal hyphae, and spores [127]. Larvae have been found on the ground in decaying vegetation, and apparently have a diet similar to that of adults [127].

\section{Meloidae (Blister Beetles)}

Except for a few genera, which do not feed, Meloidae adults are, in general, phytophagous, feeding on flowers and leaves of a wide range of plant species [128]. Larvae are predaceous, mostly feeding on the eggs of Acridoidea or provisions and larvae of various aculeate Hymenoptera, primarily bees [129]. The Meliodae individuals collected in DDR belong to the Berberomeloe castuo. Species of Berberomeloe feed on Anthophoridae and Andrenidae bees, and perhaps also on Megachilidae (Apoidea: Hymenoptera) [130].

\section{Tenebrionidae (Darkling Beetles)}

Tenebrionidae are primarily detritivorous; many species are associated primarily with dead or rotting wood or other vegetation and ground litter. Others feed on lichens and fungi on dead plant material [131]. Tenebrionids live on the ground, under logs, stones and litter, and in or under bark on trees, and some can also be observed in birds' nests and in the nests of ants and termites [131]. In DDR, the tenebrionids found were mostly from Gonocephalum spp., Phylan spp., Tentyria spp. and Akis lusitanica Solier, 1836.

\section{Buprestidae (Wood-Boring Long-Horned Beetles)}

Many Buprestidae adults are attracted to dead or dying trees and logs, while others live on the foliage of trees and shrubs. The larvae of most species bore under bark or into wood, attacking living trees, or newly cut or dying logs and branches [105]. The species Xylotrechus arvicola (Olivier, 1795) (identified in Portugal, but as far as we know, not yet in vineyards), is becoming an important pest in several Spanish vine-growing areas [132]. In vines, the larvae, commonly known as "vine screw", dig large galleries inside the wood, causing progressive stunting, and eventual death of the affected branches, which end up affecting the yield and quality of the wine [132].

\section{Elateridae (Click Beetles)}

Adults of Elateridae are phytophagous and live on flowers, under bark, or on vegetation [105]. Many Elateridae larvae are also phytophagous, representing important agricultural pests; others, particularly in forests, also feed exclusively or opportunistically on insects, being classified as predators or omnivorous [133].

\section{Geotrupidae (Scarab Beetles)}

Geotrupidae, also called "earth-boring dung beetles", are either detritivorous feeding on underground fungi, herbivores, or are coprophagous (feeding on dung) [134]. Adults can live in the soil or in vegetation; some feed on dung, others on pollen and nectar, plant sap, and fruits, while others do not feed at all [134]. 


\section{Scarabaeidae (Scarab Beetles)}

Scarabaeidae larvae live in the soil where they feed on decomposing organic matter, dung, decaying wood or roots of living plants. Adults can live in the ground or vegetation; some feed on dung, others on pollen and nectar, plant sap, and fruits, while others do not feed at all [134]. Due to their high sensitivity, they can be good indicators of the environmental changes due to human activities and habitat disturbance [6].

\section{Scydmaenidae (Antlike Stone Beetle)}

Scydmaenidae live under stones, in moss and leaf litter, rotten wood, and other decaying vegetation remnants; some species are associated with ants and termites and can be found in their nests $[105,135]$. Adults and larvae are known or suspected to be predators of mites and other small organisms [136]. In DDR, Scydmaenidae were found to be exclusively represented by Palaeostigus palpalis (Latreille, 1804). Species of the Palaeostigus genus live in humid, leafy, and shady areas where they are usually found in very numerous colonies in mosses, plant debris, under stones, or in the vicinity of water courses [137].

\section{Staphylinidae (Rove Beetles)}

Staphylinidae (Figure 5b) generally live on or in the soil, in ground litter, moss, or in decomposing organic matter $[105,109]$. They can also be found under stones or in the nests of birds, mammals, ants, and termites [105]. Adults are able to climb onto vegetation, especially at night, and hunt for prey [138]. Most Staphylinidae are generalist predators, feeding on various soil arthropods, such as nematodes, mites, Collembola, small insect imagos, and larvae [139]. Some species have specialized in eating ants and termites [139], and other feed on various organic substances or pollen [139]. Others live and feed on mushrooms and other fungi. Nevertheless, a few species are parasitoids [140] or plant feeders [141].

Rove beetles are important elements of sustainable agriculture and can be used as bioindicators of the environmental status and particularly of human influence on ecosystems [139]. Thus, these insects are good indicators of changes in management practices, such as tillage, manuring and NPK fertilizer application, as well as environmental pollution (such as pesticides and heavy metals) [139]. Rove beetles react sensitively to habitat changes, and according to Marcelino et al. [142], anthropogenic influence in different habitats can contribute to the increase in species richness and abundance of a few opportunistic species, with limited genetic variability, possibly compromising the viability of less competitive and unique species. Moreover, Weithmann et al. [143] found that an increasing human impact in forests changes rove beetle communities by promoting generalist and more open-habitat species coping with low structural heterogeneity.

In the DDR vineyard soils, five species of Staphylinidae were identified: Anotylus inustus, Dalotia coriaria, Ocypus (Ocypus) olens Quedius semiobscurus and Sepedophilus nigripennis, and individuals of three more genera, Oxypoda sp., Oligota sp. and Medon sp. From their relative abundance, we highlight Ocypus (Ocypus) olens, Dalotia Coriaria, and Quedius semiobscurus that have predator habits [144], and Anotylus inustus, which is a detritivorous species [144].

\subsubsection{Dictyoptera (Isoptera) (Termites)}

Termites (Figure 5c), popularly referred to as "white ants", are detritivorous insects that can feed on plant material in the form of sound wood and/or at different stages of humification, such as leaf litter, humus, and soil organic matter [145]; some species feed on fungi, which they cultivate in their nests [146]. There are also species that may become pests due to the adoption of wrong agricultural practices, such as the ones related to the decrease of available food (reduced plant litter), the reduction of termite diversity (with the consequent decrease in inter-specific competition, and the proliferation of resistant or invasive species), landscape simplification (fewer predators leading to a lower control of termite populations), and a reduction in plant resistance [147]. In DDR, termites are 
referred to as being an important grapevine pest although, apparently, they are usually associated with plants that are severely weakened or killed by wood diseases. Although termites possess the characteristics of good bioindicators, their value as an ecological indicator is not yet proven [6]. Nevertheless, the reduction in termite diversity is related to land use intensity $[148,149]$ and habitat disturbance [148], and the absence of a termite group could be used as a bioindicator of environmental quality $[150,151]$. In the soils from the DDR vineyards, termites represented less than $0.01 \%$ of the total soil-surface, and about $0.1 \%$ of the soil-living arthropods collected (Tables 1 and 2).

\subsubsection{Diptera (Flies)}

Diptera have a diversity of lifestyles and eating behavior. Adults feed on various plant or animal juices, such as nectar, honeydew, and sap [105]. The larvae of some species are phytophagous; some are useful detritivores, while others are important predators or parasitoids of arthropods. Depending on their feeding habits, larvae live in many kinds of habitats; phytophagous species generally live within some plant tissue; the predaceous live in the habitats of their main prey (in the water, in the soil, under bark or stones, or on the vegetation); detritivorous species feed and live on decaying plant or animal matter [105].

According to Frouz [152], Diptera can, based on their relation to the soil, be divided into three groups: (i) they dwell in the soil throughout their entire life; (ii) they spend all their stages of immature development in the soil, from which they emerge as adults; (iii) they grow on specific substrates, such as vegetable tissue or carrion, and only pupate in the soil.

The main natural factors that affect Diptera communities in the soil are moisture and organic matter [152]. Diptera present characteristics that make them useful as bioindicators: they are variable in terms of size, ecological demands, and their position in food webs; their larvae are widespread and abundant in the soil; and some species play important roles in soil biological functions such as plant litter decomposition [152]. Thus, they can be good indicators of changes in management practices, such as tillage, manuring, fertilizer application, environmental pollution (pesticides and heavy metals), and drainage [152]. However, difficulties of taxonomic identification at species level, together with their great heterogeneity and ecological needs, are significant obstacles to the broader use of soil dwelling Diptera as bioindicators [6,152].

In the soils from the DDR vineyards, Diptera (larvae) represented about $0.7 \%$ of the total soil-living arthropods collected (Table 2).

\subsubsection{Embioptera (Webspinners)}

Embioptera live beneath the ground in a labyrinth of silken galleries spun in leaf litter, under stones, or in bark crevices wherever it is humid and warm [105,153]. Females and immatures are detritivorous feeding on leaf litter, outer bark surfaces, and epiphytic algae and lichens [153]; adult males do not eat [105] and die soon after mating [153]. Embioptera are a poorly studied group in soil monitoring research [6]. In the soils from the DDR vineyards, Embioptera represented less than $0.01 \%$ of the total soil-surface (and $0.03 \%$ of the total soil-living) arthropods collected (Tables 1 and 2).

\subsubsection{Hemiptera}

Hemiptera, as the most significant non-holometabolous order of insects [154], varies considerably in morphology, life history, and eating habits [105]. Traditionally, they have been categorized into 'Homoptera' and Heteroptera. More recently, they have been subdivided into four major suborders: Cicadomorpha, Fulgoromorpha, Heteroptera, and Sternorrhyncha [32]. Cicadomorpha, Fulgoromorpha, and Sternorrhyncha are phytophagous, feeding on the phloem or xylem of plants, while Heteroptera include predators and phytophagous species [105]. Hemiptera have been used as indicators of pollution [35]. In the soils of the DDR vineyards, Hemiptera represented $0.5 \%$ and $0.3 \%$ of the total soilsurface and soil-living arthropods collected, respectively (Tables 1 and 2), and they were 
included in the families Dictyopharidae from Fulgoromorpha and Cydnidae, Lygaeidae, Pentatomidae, Rhopalidae, and Scutelleridae from Heteroptera.

\section{Dictyopharidae (Dictyopharid planthoppers)}

Dictyopharidae are phytophagous, and most species are predominantly Dicotyledoneae feeders, although only a few species are economically important agricultural pests on grasses [155]. In Europe, Dictyophara (Dictyophara) europaea (Linnaeus, 1767), is a polyphagous phloem-feeding planthopper, already found in DDR [156], involved in the transmission of Flavescence dorée (FD) phytoplasma disease of grapevine [157]. Some species, as in the case of D. europaea, have a complex oviposition strategy, which consists of protecting the eggs by hiding them in soil particles and then dropping them onto the soil surface ('soil nests') [157]. Such a strategy provides good protection, making detection by predators difficult, and facilitating egg dispersal by the wind [157].

Cydnidae (Burrower Bugs)

Cydnidae usually dig in the ground, being found beneath stones or boards, in sand, or around the roots of plant hosts [105]. They are phytophagous, and most of the nymphs and adults of this group are sap-feeding through the roots of hosts. However, some species (particularly from Sehirinae and Amnestinae subfamilies), feed on the aboveground structures of the host plants (such as fruits, seeds and other plant organs) [158]. Most species are of little economic importance, and only occasionally do they become abundant and cause injury to crops [159].

Lygaeidae (Seed Bugs)

Although a few Lygaeidae are ground-living; the majority tend to live aboveground [105]. Most are phytophagous, feeding on seeds or plant sap, and only a few are predatory [160]. Many species live on plants above ground level, while others live on the ground in the litter layer, where they feed on fallen seeds, although they can climb plants to feed on mature seeds [160].

\section{Pentatomidae (Stink Bugs)}

Most species of Pentatomidae are phytophagous (feeding on all aboveground plant parts, including stems, petioles, leaves, flowers, fruits, and seeds), although some (from the Asopinae subfamily) can be predators and others are omnivorous [161]. Pentatomidae occur in a diversity of habitats, ranging from natural to cultivated, and from herbaceous to arboreal [161]. Females generally lay their eggs in clusters on plant organs, such as the undersides of leaves [161]. However, some species reportedly lay their eggs on detritus or on soil beneath plants, or even in cracks in the soil surface [162].

\section{Rhopalidae (Scentless Plant Bugs)}

Rhopalidae live principally on weeds, but a few are arboreal [105]. All are phytophagous (feeding on seeds, fruits) [105], although in general they have little economic importance [159]. To varying extents, they specialize on a particular host plant taxon as a food source, although they may take water or nutrients from other sources, including flowers, fruits, and dead insects [163]. Females typically lay their eggs on or near host plants [163] and in some species, females dig a hole in the soil, lay their eggs there, and cover them with soil [164].

\section{Scutelleridae (Shield-Backed Bug)}

All Scutelleridae species are phytophagous, with the majority showing a broad preference for plants of Rosidae and Asteridae, although some are specialized into feeding on Poales [165]. They can be an important pest of grain crops [105,159], although a few otherwise phytophagous species are occasionally attracted to carrion [165]. 


\subsubsection{Hymenoptera}

Hymenoptera are traditionally subdivided into three groups (the paraphyletic suborder Symphyta, and the monophyletic Aculeata and Parasitica, belonging to the sub-order Apocrita), each one exhibiting different biology [166]. Symphyta are mostly phytophagous, while Parasitica are mainly parasitic species, although some of them have returned secondarily to phytophagy, and Aculeata comprise predators, parasitoids, and phytophagous individuals. All eusocial Hymenoptera belong to the last group [166]. Given this, Hymenoptera play an important role in virtually all terrestrial ecosystems and are of substantial economic importance. Moreover, mainly due to their assemblage composition and richness, they have been found to be useful ecological indicators [35]. In the DDR vineyard soils, Hymenoptera represented about $28.7 \%$ of the total soil-surface and $7.3 \%$ of the soil-living arthropods collected (Tables 1 and 2). Hymenoptera from the surface were included in three families from two super-families, namely: Dryinidae (Dryinidae), Formicidae and Mutillidae (Vespoidea), Formicidae being the most representative family.

\section{Dryinidae}

Dryinidae are parasitoids of adults and nymphs of Hemiptera Auchenorrhyncha [105,167]. Females are often brachypterous or apterous and similar to ants in their general appearance and behavior $[167,168]$. This mimicry allows Dryinidae to attack easily their hosts Auchenorrhyncha, because ants frequently feed on the honeydew produced by those insects defending them from natural enemies [167]. Males do not feed or feed only on sugar solutions. Females have developed their predatory behavior to obtain energy and nutrients necessary for egg production [167], and after sugar solutions, feed on the hemolymph and tissues of their hosts [168].

\section{Formicidae (Ants)}

Formicidae (Figure 5d) have colonized most terrestrial habitats and form organized colonies of variable sizes in the soil, plant debris, trees, and buildings [166]. Most species are omnivorous [169]. However, there are also predator species [170], phytophagous [171-173], detritivorous (feeding on decaying organic matter, thereby accelerating the decomposition process) [174], as well as species that feed on honeydew [175], pollen [176], extrafloral nectar, and glandular corpuscles [177-179].

Once Formicidae are abundant, diverse, present in most habitats, and easily recorded, they are the Hymenoptera family most widely used as a bioindicator [6]. Thus, they have been used in environmental monitoring [180,181], and changes in ant communities reflect broader ecological change [182].

In the DDR vineyard soils, Formicidae from the soil-surface were grouped into three subfamilies, 13 genera, and 24 species (Table S5). The most abundant ant species were Messor barbarus, a phytophagous species that feeds essentially on seeds, and Pheidole pallidula, Tapinoma nigerrimum, and Aphaenogaster gibbosa, all omnivorous species. Three species, e.g., Cataglyphis iberica, Cataglyphis hispanica, and Aphaenogaster iberica are endemic to the Iberian Peninsula (Table S5).

\section{Mutillidae (Velvet Ants)}

Mutillidae (Figure 5e) are generally found in arid areas [105]. Females are apterous and spend most of the daytime in burrows in the ground or under grass turfs, while winged males, searching for virgin females to mate with, usually fly just above the ground [183]. They are parasitoids in nests of various wasps and bees [105,183]. Females feed on adults or immature offspring of the hosts [184] and both females and males feed on nectar, honeydew [184] and extrafloral nectar [185].

\subsubsection{Orthoptera}

Orthoptera is a large and diverse order of insects that includes two suborders, Ensifera and Caelifera $[32,186]$. They are found in all terrestrial habitats, and a number live 
underground [186]. Orthopterans are mainly phytophagous, feeding on different plant structures such as leaves, flowers, and fruits. However, many species are omnivorous, consuming various living and dead organic food material including plants, fungi, lichens, algae, mosses, and feces [187]. They may also be detritivorous, feeding on dead arthropods and dead vertebrates, while a few groups may be considered predators [186]. Orthoptera are sensitive to climatic conditions and their abundance and diversity are correlated with vegetation structure rather than plant composition [6]. They are considered effective ecological and environmental indicators, particularly in grasslands [6,35]. In the soils of the DDR vineyards, Orthoptera represented $0.4 \%$ of the soil-surface arthropods collected (Table 1 ) and were included in the Acrididae family, in the Caelifera sub-order, and Gryllidae, and Gryllotalpidae in the Ensifera sub-order.

\section{Acrididae (Grasshoppers)}

Acrididae are essentially phytophagous, although there are predator and detritivorous species [188]. Grasshoppers are potentially useful as bioindicators because they have been found to indicate ecological change and the effects of habitat management. Moreover, they may also be sensitive to pollution [35].

\section{Gryllidae (True Crickets)}

Gryllidae (Figure 5f) occur in varied habitats and sometimes are found in the soil, hiding under dead plants or in burrows that they excavate. The feeding habits are diverse. Many species are detritivorous, feeding on organic remains, decaying plants, and fungi. There are also species that are strictly phytophagous (feeding on flowers, fruit, and leaves), while others are mostly predatory.

In general, females lay their eggs in the ground or in the vegetation [105]. Like grasshoppers, crickets are potentially useful as bioindicators of ecological change, habitat management, and pollution [35].

In DDR, the Gryllidae were found represented by Gryllus spp. and Sciobia lusitanica. The Gryllidae species S. lusitanica (the Lusitanian spade-cricket), observed in soil of DDR vineyards with some frequency, is an Iberian-Moroccan endemic species [189], sensitive to changes in habitat. This species is reported to occur in association with the plants Cistus ladanifer, Lavandula stoechas, and Erica arborea [190,191], which are common in the neighboring non-crop habitats of DDR vineyards.

\section{Gryllotalpidae (Mole Crickets)}

Gryllotalpidae are omnivorous, feeding on various food sources, such as above ground grass leaves, seedlings of vegetables, roots, and earthworms, and soil arthropods, including other mole crickets [192]. They spend almost all of their lives underground and form tunnels for feeding, protecting, and mating [193]. In DDR, this family was represented by Gryllotalpa spp.

\subsubsection{Lepidoptera (Moths)}

The larvae of most Lepidoptera species are phytophagous, feeding in different ways: many are leaf miners, feeding inside the leaf; a few are gall makers, and a few bore in the fruits, stems, wood, or other parts of the plant [105], such as live roots [9]. A very few are predaceous on other insects [105]. Some species also pupate in the soil [105]. Lepidoptera have been used to indicate habitat changes, management practices, and pollution [35]. Lepidoptera represented about $0.6 \%$ of the total soil-living arthropods captured in the soils of the DDR vineyards (Table 2).

\subsubsection{Neuroptera (Lacewings)}

Neuroptera larvae are diverse in habits; larvae of most species are active and generalist predators, although some can feed on decaying plant material [194]. According to their feeding habits, they can occur widely on vegetation, on litter or on the bark of trees, often 
extremely well camouflaged [194]. Some species inhabit the egg sacs of various spider species, where they feed on the contents; other larvae live in the soil, possibly being generalist predators, or they live in the nests of social insects, such as ants and termites where they feed on the inhabitants [195]. Individuals of the family Myrmeleontidae (antlions) create "pitfall traps", and eat small arthropods that fall in [9]. Adults can be predators, omnivorous (feeding opportunistically on soft-bodied insects, pollen, and honeydew), and phytophagous (some are obligate feeders on pollen and nectar from flowers) [195]. Neuroptera have been used as an indicator of management practices and pollution levels [35]. Neuroptera represented about $0.01 \%$ of the total soil-living arthropods collected in the soils of the DDR vineyards (Table 2).

\subsubsection{Thysanoptera (Thrips)}

A great number of species of Thysanoptera are phytophagous, feeding on flowers, leaves, fruits, twigs, or buds of a wide variety of plants [105]. Other species consume fungal spores and hyphae [196], and a few are predators of other small arthropods [105]. Some species, such as the well-known Frankliniella occidentalis are omnivorous, feeding on plants and arthropods [196]. According to their feeding habits, they can live on young leaves, flowers, and leaf litter, or within the bases of grass and sedge tussocks [197]. Some species overwinter as a pupa and/or adult in the soil [105]. Thysanoptera were used in the indication of the effects of habitat management, but have rarely been used [35]. Thysanoptera represented about $0.08 \%$ of the total soil-living arthropods collected in the soils of the DDR vineyards (Table 2).

\subsection{Myriapoda Chilopoda (Centipedes)}

Chilopoda (Figure 6a) mostly inhabit leaf litter and the soil or are found under stones and bark [198]. As they are particularly sensitive to drying, due to their weak epicuticular wax layer on the epidermis [199], they tend to be buried or sheltered.

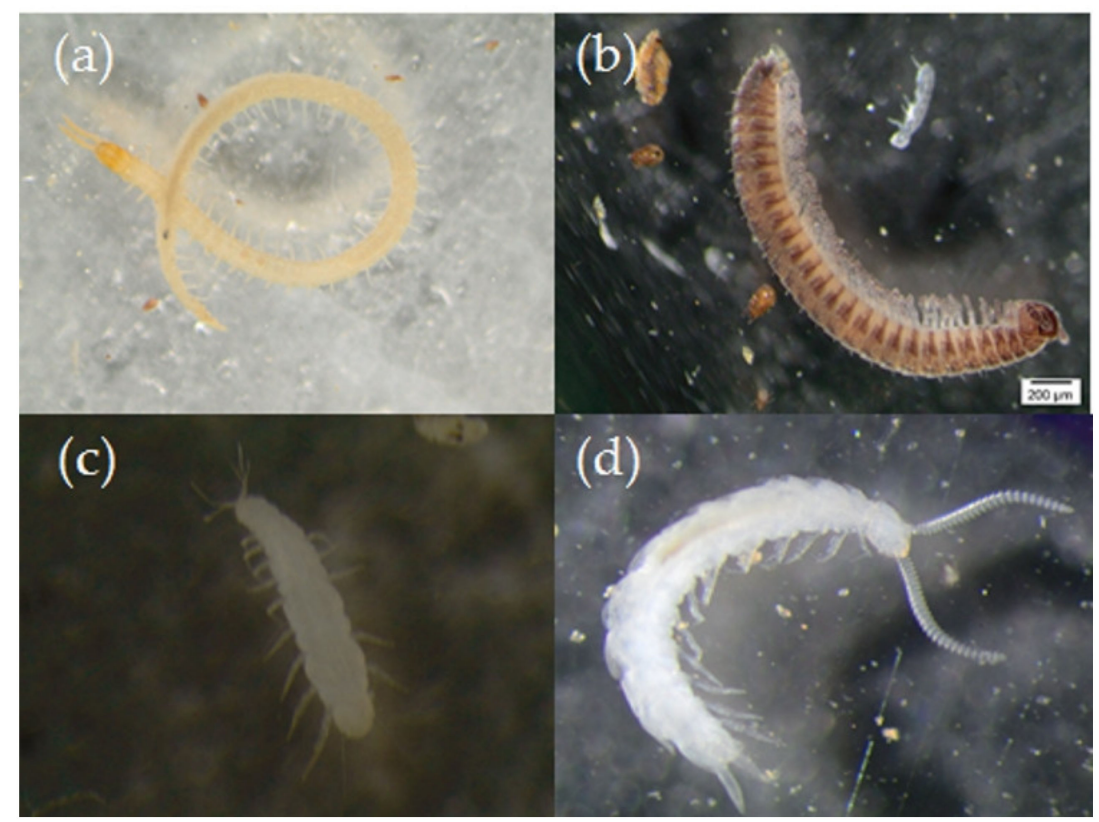

Figure 6. Chilopoda (a), Diplopoda (b), Pauropoda (c), and Symphyla (d) common in vineyard soils from the Douro Demarcated Region.

In the soils of the DDR vineyards, Chilopoda represented $0.1 \%$ and $0.5 \%$ of the soilsurface and soil-living arthropods collected, respectively (Tables 1 and 2), and they were included in the orders Geophilomorpha, essentially in the soil-living community, and Lithobiomorpha and Scutigeromorpha, in the soil-surface community. 
Individuals of the Geophilomorpha order, also known as "sub-ground centipedes", which are specialized in living in deeper layers of the soil, can move skillfully through the narrow system of sub-ground channels [7] and are not much affected by temporary flooding [97]. Especially when conditions get hostile (heat, cold, drought, predators), they move vertically in the soil [97].

On the other hand, species from the Lithobiomorpha and Scutigeromorpha orders that live closer to the soil surface cannot dig, but need shelter, because they are also susceptible to drought [97]. Thus, for example, in the case of Lithobiomorpha, also known as "stone centipedes", they rest during the day in crevices under stones, tree trunks or bark, or seek the shelter of moist stacks of leaves within the litter, becoming active and starting to hunt at night, when the air humidity increases [7].

Chilopoda is an important group of generalist predators in many terrestrial habitats [200]. They feed on a broad spectrum of soil invertebrates, including small insects, Collembola, acari, nematodes, enchytraeids, and even earthworms [9,201]. Some species have specialized diets: thus, there are species of Lithobiomorpha that feed preferentially on Collembola and oribatid mites [202], while some species of Geophilomorpha feed preferentially on bacteria eaters, such as lumbricids and enchytraeids [202].

Chilopoda have been referred to as potentially useful indicators of habitat quality [203], signaling the detrimental effects of pollutant accumulations (protons, heavy metals) [204] and pesticide applications [205]. However, Klarner et al. [206] found that in ecosystems undergoing major structural changes due to anthropogenic land use, they are able to change diet and utilize alternative prey, persisting in these ecosystems.

\subsection{Myriapoda Diplopoda (Millipedes)}

Diplopoda (Figure $6 b$ ) live, generally, in the upper soil layer and in leaf litter where it is moist, under rocks, logs, or bark, preferring calcareous soils [5]. Usually they are active at night [37]. Like Chilopoda they are particularly sensitive to drying out [199].

In general, Diplopoda are detritivorous, feeding on decaying leaves and other debris from dead plants. A few species are omnivorous or predators, feeding on small arthropods, such as insects and centipedes, or on earthworms [9].

Diplopoda are potentially useful indicators of the habitat quality [203] and the diversity of the decomposer communities in leaf litter and upper soil layers [35]. Moreover, they are bioindicators of metal pollution in soils [207]; some species react positively to the presence of metals [207], while others are very negatively affected $[207,208]$. They are also useful indicators of restoration success [209].

In the soils of the DDR vineyards, Diplopoda represented $0.07 \%$ and $0.1 \%$ of the soil-surface and soil-living arthropods collected, respectively (Tables 1 and 2).

\subsection{Myriapoda Pauropoda}

Pauropoda (Figure 6c) live mainly in the soil, but sometimes occur in leaf litter, rotting logs, under bark and moss [210]. They inhabit various plant communities and soil types, occurring on decaying logs or under bark and moss [210], preferring undisturbed habitats with high organic matter content and rich in pore spaces [211]. They are particularly susceptible not only to soil humidity but also to light and temperature. When the upper layers dry, Pauropoda look for moisture in deeper layers always using the interstices of the ground, as they cannot build galleries or dig burrows [212]. Their occurrence is often very patchy and the populations are sparse [210,212].

Pauropoda are thought to feed on soil microflora, sucking out root hairs, and decaying organic matter of plant and animal origin [211]. However, at least one species has already been reported as damaging plants in a greenhouse [212].

Pauropoda have been referred to as a bioindicator of management systems in which their population densities decrease in high-input management systems, apparently due to the mechanical and chemical disturbances, and unfavorable abiotic soil conditions existing in intensively managed sites [13]. In addition, Ochoa-Hueso et al. [213] have 
also suggested them as potential bioindicators because their abundance increases with the nitrogen deposition in the soil, possibly being related to alterations in the quality and quantity of organic matter following nitrogen additions.

In the soils of the DDR vineyards, Pauropoda represented $0.03 \%$ of the soil-living arthropods collected (Table 2).

\subsection{Myriapoda Symphyla}

Symphyla (Figure 6d) live in soils, mainly from undisturbed habitats with high organic matter content and rich in pore spaces [97,212]. In humid environments, some individuals can also be found in the leaf litter and under the bark of trees, to where they migrate during flooding [214].

Symphyla are divided into two families: Scolopendrellidae e Scutigerellidae [32]. Individuals of Scolopendrellidae are supposed to be detritivorous, feeding primarily on decaying organic matter and on fungi [215]. However, predator behavior has been documented in the Symphylella genera, and it is believed that predatory habits are more widespread within the Scolopendrellidae family [215]. Individuals of Scutigerellidae are phytophagous feeding on roots (fine roots and root hairs) and other plant material [215] and can damage plants if the population density is high $[7,216]$.

Factors that regulate Symphyla distribution are high humidity, temperature, a noncompact substrate, and food presence [212]. During spring and early summer, they can migrate in high numbers to the soil surface, while during warm summer periods, when the upper soil dries out, the populations withdraw to deeper soil layers [217], although they are not able to build galleries or dig burrows and have to use existing soil cracks and tunnels $[97,212]$.

Symphila represented $0.7 \%$ of the soil-living arthropods collected in the soils of the DDR vineyards (Table 2).

\section{Ecosystem Services Provided by Soil Arthropods in the Vineyard}

Ecosystem services, which can be defined as those benefits that people obtain from ecosystems, may be categorized as: (i) provisioning services, which are the material goods that people get from ecosystems, such as food, water, fibers, wood, and fuels; (ii) regulating services, which are those by which ecosystems regulate other environmental factors or processes, such as biological control, pollination, flood regulation, water purification, and climatic regulation; (iii) cultural services, which include non-material benefits that people obtain from ecosystems, e.g., recreational, spiritual, and aesthetic values); and (iv) supporting services that are ecosystem processes and functions necessary for the production of other ecosystem services, such as nutrient cycling, soil formation, and habitat provision for biodiversity [218]. However, the ecosystem could also generate functions, processes, and attributes viewed as harmful and with negative impacts on human wellbeing denominated as ecosystem disservices [219]. Examples of ecosystem disservices are pest damages, which reduce productivity and often lead to an increase of the chemical inputs and, consequently, in the increase of pollution, and the increase/occurrence of intraguild predation in which a predator feeds not only on the pest, but also on another predator or parasitoid [220].

Soil organisms, including arthropods, influence soil processes that contribute to the provision of a wide range of essential ecosystem services that are critical to the sustainability of ecosystems [3]. Although soil arthropods can contribute to all ecosystem service categories, we focus on their roles in supporting and regulating services.

The decomposition of organic materials into simpler molecules is one of the most important ecosystem services of soil organisms [3]. In DDR, detritivores populations ranged between 41.3 and 70.2\% [14,31]. Soil detritus feeders, also known as "litter transformers", of which the microarthropods Acari and Collembola comprise a large part, significantly contribute to the removal of organic matter from the litter layer and the incorporation of the mineral soil [221]. They fragment, or comminute, and humidify ingested plant 
debris, improving its quality as a substrate for microbial decomposition and promote the growth and dispersal of microbial populations [5]. Apparently, the most consistent effect of arthropods in decomposing leaf litter is an increased rate of nitrogen mineralization, which results predominantly from interactions with microorganisms and not from excretions [222]. The rate of leaf litter decomposition is significantly faster than decomposition of soil fauna feces produced from the same litter, as they are poor in easily assimilable organic compounds and rich in lignin; however, the incorporation of feces in the mineral soil affects many other soil properties, including microbial activity [221,222]. Several other groups of arthropods are also included in this key regulatory group, with importance in litter fragmentation and decomposition, stimulation of microbial activity and nutrient recycling. These are terrestrial isopods [70], Diplopoda [223], Diptera [152], Embioptera [224], ants [174], and termites [145]. Protura, Diplura, and Pauropoda are of lesser importance in the soil community having little influence on soil processes [5]. Apparently, their most important contribution is to stimulate microbial activity and propagate spores [7].

Concerning phytophagous, in DDR, their populations ranged between 1.3 and $8.8 \%[14,31]$. While the effects of many phytophagous might often be considered as disservices, they can also be seen as regulators [225]. Thus, with the exception of some species of the Chrysomelidae (e.g., A. ampelophaga) and Curculionidae (e.g., O. sulcatus) families, which spend part of their life cycle in the soil and are known to feed on vine leaves and tender shoots, most of the herbivores found in the soil vineyards of DDR do not feed on vines [14]. They can be helpful to control weeds, through herbivory, or pests, through competitive exclusion or by helping to maintain the populations of generalist predators and parasitoids, as alternative prey or host [225]. Thus, many of the herbivores found are predators of weed seeds. This is the case of some carabids (e.g., Harpalus and Amara genus) [226], M. barbarus (Formicidae) [173] (Table S3), isopods [70], and crickets [227]. The importance of weed seed predators in controlling weeds and, consequently, reducing the need for traditional weed control practices, such as the use of herbicides, has been highlighted by Blubaugh et al. [228]. In addition, herbivores also influence nutrient cycles and nutrient availability in the soil, thus contributing to soil fertility and increasing primary production [225].

Predation on other arthropods or on microbial populations is also considered a regulating ecosystem service provided by arthropods. Even by inhabiting the ground, soil predators may be potentially important in the natural control of vineyard pests since many of them search for their prey both on the soil surface and in the crop canopy [229] and may link the food webs between the ground cover and the vineyard canopy [230]. In the case of spiders, Roltsch et al. [231] suggested that some species could move between the ground cover and the canopy in Californian vineyards. Moreover, adults of Carabidae and Staphylinidae are able to climb onto vegetation, especially at night, and hunt for prey [138,226]. Petremand [232], in studies conducted in vineyards in Switzerland, found that the peak of potentially predatory activity of carabids corresponded to the occurrence of some vine pests. Concerning Formicidae, Blaise et al. [233] found a correlation between predation on sentinel prey (located both in the soil and in the trunk) and ant abundance in pitfall traps located in the vineyard inter-row, highlighting the potential key role of ants in predation in Mediterranean vineyards.

Nevertheless, it is admissible that these predators have an important role in the control of arthropod vine pests, which spend part of their lifespan on the ground, namely O. sulcatus and A. ampelophaga, or of other vine pests or vine disease vectors that could use plants in the ground cover as hosts, such as Tetranychus urticae Koch, Scaphoideus titanus Ball., D. europaea, and Philaenus spumarius L. [14]. In addition to these organisms, predators use other prey that inhabit the soil, thus enhancing their own population densities and contributing to arthropod populations' control and biological balance. For instance, Collembola are an important food source for generalist predators [97,234], including carabid beetles and their larvae [235], and small spiders [236]. Moreover, Acari serve as food sources for soil 
predators [4]; for instance, Oribatida serve as food for centipedes, symphylans, diplurans, spiders, pseudoscorpions, opilionids, ground beetles, and ants [46].

Ants and termites are also considered important ecosystem engineers because of their effects on soil properties, and their impact on the availability of resources for other organisms, including microorganisms and plants $[237,238]$. They are able to change biological, chemical, and physical soil processes and soil environments through bioturbation (biological reworking of soils through incorporating plant litter and other residues into the soil), decomposition of soil organic matter, and facilitation and regulating of nutrient cycling $[237,239,240]$. Their activity (often associated with transport and movement of soil particles, burrowing, and mixing organic matter with mineral soil during nest building) also affects soil texture, porosity, and aggregation, significantly affecting water infiltration and reducing runoff $[147,237,238,241-243]$. Moreover, they promote soil enrichment with clay materials, organic matter and moisture that improve the soil's water holding capacity, organic matter content, and soil structure [244]. Their activity can promote the activity of the microbial community and increase the degradation rates of soil organic matter $[245,246]$. In addition, their contribution to microbial activity stimulation can positively impact soil carbon sequestration and nitrogen recycling [246]. It should be noted that water infiltration, water holding capacity and reduced runoff are of great importance in the vineyards of the Mediterranean Region, and in particular of the DDR, as it is a region with intense rainfall mainly concentrated in the spring and autumn, and whose vines are often located on steep slopes, which are susceptible to erosion [247].

Moreover, Scarabaeoidea play an essential role as ecosystem engineers by removing manure from the surface and burying it in the soil as food for their offspring [248]. The most common nesting behavior consists of tunneling, in which they dig earth tunnels of various lengths underground, underneath the feces, which terminate with hatching chambers where they put their eggs, and the offspring develop [249]. Dung beetles are beneficial to soil health by increasing organic matter content and nutrient cycling $[248,249]$. Moreover, they positively influence hydrological properties of the soil by increasing water infiltration and soil porosity, thereby reducing surface water runoff [250].

Terrestrial isopods [70] and diplopods [7] are other soil arthropods that are considered important ecosystem engineers due to their contribution to bioturbation with an essential role in mixing the soil. The Orthoptera, particularly some Gryllidae and Gryllotalpidae species, create deep burrows, modifying soil architecture and its hydrological functions, particularly the increase of water infiltration rates and the decrease of runoff [193]. Due to their relatively large dimensions and the physical disturbance that they cause in the soil, Amphipoda positively affects microbial communities [251].

\section{Conclusions}

Arthropods are a major component of soil biota and are important contributors to the delivery of vital ecosystem services to agriculture. Hence, studying soil arthropod communities is essential for understanding soil ecological functions and the link between these functions and ecosystem services. This work is a first attempt to present soil arthropod communities typical of vineyards of the DDR and describes the ecosystem services provided by them. It describes the ecology of a set of soil arthropod groups of recognized importance for their key role in the delivery of supporting and regulating ecosystem services and/or their possibilities as indicators of soil quality. Thus, some of the groups presented, such as Collembola and Acari, are important in the decomposition of organic materials through fragmentation and ingestion of plant debris, improving its quality as a substrate for microbial growth and dispersal, and improving nitrogen mineralization. At the same time, also due to their higher abundance, they also constitute important food sources for generalist predators, such as Araneae, allowing them to increase their populations and persist in the vineyards. Moreover, Collembola and Acari are also the arthropod groups typically used in soil quality evaluation approaches. 
Some phytophagous species, mainly the ones that feed on seeds, such as M. barbarus, are essential in weed control, contributing to the reduction in weed control practices, helping to maintain the populations of generalist predators. Other groups, such as Formicidae, Isoptera, Diplopoda, and Isopoda have a greater role in the soil food web, being considered important ecosystem engineers, as they are able to change soil processes and the soil environment through bioturbation, decomposition of soil organic matter, and facilitation and regulation of nutrient cycling. These all affect soil properties and impact the availability of resources for other organisms, including microorganisms and plants.

In conclusion, it is expected that the information presented here may contribute to a deeper knowledge of vineyard soil arthropods, as well as the ecosystem services and disservices provided, as a basis for the implementation of sustainable viticulture ecosystems.

Supplementary Materials: The following are available online at https:/ /www.mdpi.com/article/10 $.3390 /$ su13147837/s1, Table S1: General characteristics of the data analyzed on soil-surface arthropods from the Douro Demarcated Region, Table S2: General characteristics of the data analyzed on soilliving arthropods from the Douro Demarcated Region, Table S3: Total number of ach species and family of Araneae observed and respective functional group and habitat preference, Table S4: Total number of each species and sub-families of Carabidae observed and respective trophic groups, Table S5: Total number of each Formicidae species observed, and respective functional and trophic groups.

Author Contributions: Conceptualization, F.G. and L.T.; funding acquisition, F.G., C.C., J.A.P. and L.T.; visualization, F.G. and J.S.; writing—original draft, F.G.; writing-review and editing, F.G., C.C., L.C., V.Z., A.O., J.S., J.A.P. and L.T. All authors have read and agreed to the published version of the manuscript.

Funding: F.G., C.C. and L.T. are grateful to the Foundation for Science and Technology (FCT, Portugal) for financial support, by national funds FCT/MCTES to CITAB (UIDB/04033/2020). F.G., J.A.P. are grateful to the FCT for financial support by national funds FCT/MCTES to CIMO (UIDB/00690/2020). V.Z. is grateful to the FCT for financial support by national funds FCT/MCTES to CEF (UIDB/00239/2020) and by the scholarship within the FLUVIO-River Restoration and Management, PD/BD/142882/2018. This work was funded by the European Social Fund (ESF) through the Regional Operational Program North 2020, within the scope of the Program "Contratação de Recursos Humanos Altamente Qualificados", Norte-06-3559-FSE-000188.

Institutional Review Board Statement: Not applicable.

Informed Consent Statement: Not applicable.

Data Availability Statement: The data presented in this study are available in the article and Supplementary Materials.

Conflicts of Interest: The authors declare no conflict of interest. The funders had no role in the design of the study; in the collection, analyses, or interpretation of data; in the writing of the manuscript, or in the decision to publish the results.

\section{References}

1. European Commission. The Factory of Life. Why Soil Biodiversity Is so Important; Office for Official Publications of the European Union: Luxembourg, 2010; p. 22.

2. Roger-Estrade, J.; Anger, C.; Bertrand, M.; Richard, G. Tillage and soil ecology: Partners for sustainable agriculture. Soil Till. Res. 2010, 111, 33-40. [CrossRef]

3. Barrios, E. Soil biota, ecosystem services and land productivity. Ecol. Econ. 2007, 64, 269-285. [CrossRef]

4. Stockdale, E.A.; Watson, C.A. Managing Soil Biota to Deliver Ecosystem Services; Natural England Commissioned Reports No 100; Newcastle University: Newcastle, UK, 2012; p. 141.

5. Culliney, T.W. Role of Arthropods in Maintaining Soil Fertility. Agriculture 2013, 3, 629-659. [CrossRef]

6. Menta, C.; Remelli, S. Soil Health and Arthropods: From Complex System to Worthwhile Investigation. Insects 2020, 11, 54. [CrossRef]

7. Eisenbeis, G. Biology of Soil Invertebrates. In Intestinal Microorganisms of Termites and Other Invertebrates; König, H., Varma, A., Eds.; Soil Biology; Springer: Berlin, Germany, 2006; Volume 6, pp. 3-53. 
8. Wurst, S.; De Deyn, G.B.; Orwin, K. Soil Biodiversity and Functions. In Soil Ecology and Ecosystem Services; Wall, D.H., Bardgett, R.D., Behan-Pelletier, V., Herrick, J.E., Jones, T.H., Ritz, K., Six, J., Strong, D.R., van der Putten, W.H., Eds.; Oxford University Press: Oxford, UK, 2013; pp. 28-44.

9. European Commission. European Atlas of Soil Biodiversity; Jeffery, S., Gardi, C., Jones, A., Montanarella, L., Marmo, L., Miko, L., Ritz, K., Peres, G., Römbke, J., van der Putten, W.H., Eds.; Publications Office of the European Union: Luxembourg, $2010 ;$ p. 127.

10. Parisi, V.; Menta, C.; Gardi, C.; Jacomini, C.; Mozzanica, E. Microarthropod communities as a tool to assess soil quality and biodiversity: A new approach in Italy. Agric. Ecosyst. Environ. 2005, 105, 323-333. [CrossRef]

11. Galli, L.; Capurro, M.; Menta, C.; Rellini, I. Is the QBS-ar index a good tool to detect the soil quality in Mediterranean areas? A cork tree Quercus suber L. (Fagaceae) wood as a case of study. Ital. J. Zool. 2014, 81, 126-135. [CrossRef]

12. Çakır, M. The impact of wood ants (Formica rufa) mound on soil biological quality (QBS-ar) in a semi-arid pine forest. Pedobiologia 2019, 77, 150593. [CrossRef]

13. Vignozzi, N.; Agnelli, A.E.; Brandi, G.; Gagnarli, E.; Goggioli, D.; Lagomarsino, A.; Pellegrini, S.; Simoncini, S.; Simoni, S.; Valboa, G.; et al. Soil ecosystem functions in a high-density olive orchard managed by different soil conservation practices. Appl. Soil Ecol. 2019, 134, 64-76. [CrossRef]

14. Gonçalves, F.; Nunes, C.; Carlos, C.; López, Á.; Oliveira, I.; Teixeira, B.; Crespí, A.; Pinto, R.; Costa, C.A.; Torres, L. Do soil management practices affect activity density, diversity, and stability of soil arthropods in vineyards? Agric. Ecosyst. Environ. 2020, 294, 106863. [CrossRef]

15. Galli, L. An user friendly tool to assess the effects on agricultural soils of different practices: The QBS-ar index. Mod. Concept Dev. Agron. 2020, 6, 680-682.

16. Sánchez-Bayo, F.; Wyckhuys, F.A.G. Worldwide decline of the entomofauna: A review of its drivers. Biol. Conserv. 2019, 232, 8-27. [CrossRef]

17. Sofo, A.; Mininni, A.N.; Ricciuti, P. Soil Macrofauna: A key factor for increasing soil fertility and promoting sustainable soil use in fruit orchard agrosystems. Agronomy 2020, 10, 456. [CrossRef]

18. Trivellone, V.; Paltrinieri, L.P.; Jermini, M.; Moretti, M. Management pressure drives leafhopper communities in vineyards in Southern Switzerland. Insect Conserv. Divers. 2012, 5, 75-85. [CrossRef]

19. Karimi, B.; Cahurel, J.-Y.; Gontier, L.; Charlier, L.; Chovelons, M.; Mahé, H.; Ranjard, L. A meta analysis of the ecotoxicological impact of viticultural practices on soil biodiversity. Environ. Chem. Lett. 2020, 18, 1947-1966. [CrossRef]

20. Winter, S.; Bauer, T.; Strauss, P.; Kratschmer, S.; Paredes, D.; Popescu, D.; Landa, B.; Guzmán, G.; Gómez, J.A.; Guernion, M.; et al. Effects of vegetation management intensity on biodiversity and ecosystem services in vineyards: A meta-analysis. J. Appl. Ecol. 2018, 55, 2484-2495. [CrossRef] [PubMed]

21. Nicholls, C.I.; Altieri, M.A.; Ponti, L. Enhancing plant diversity for improved insect pest management in northern California organic vineyards. Acta Hortic. 2008, 785, 263-278. [CrossRef]

22. Vaudour, E.; Costantini, E.A.C.; Jones, G.V.; Mocali, S. An overview of the recent approaches to terroir functional modelling, foot printing and zoning. Soil 2015, 1, 287-312. [CrossRef]

23. Costantini, E.A.C.; Agnelli, A.E.; Fabiani, A.; Gagnarli, E.; Mocali, S.; Priori, S.; Valboa, G. Short-term recovery of soil physical, chemical, micro- and mesobiological functions in a new vineyard under organic farming. Soil 2015, 1, 443-457. [CrossRef]

24. Viers, J.H.; Williams, J.N.; Nicholas, K.A.; Barbosa, O.; Kotzé, I.; Spence, L.; Webb, L.B.; Merenlender, A.; Reynolds, M. Vinecology: Pairing wine with nature. Conserv. Lett. 2013, 6, 287-299. [CrossRef]

25. Instituto do Vinho do Porto e Douro. Área de Vinha e Sua Composição. 2021. Available online: https://www.ivdp.pt/ (accessed on 3 May 2021).

26. Andresen, T.; De Aguiar, F.B.; Curado, M.J. The Alto Douro Wine Region greenway. Landsc. Urban Plan. 2004, 68, 289-303. [CrossRef]

27. Andresen, T.; Rebelo, J. Assessment of the State of Conservation of the Property Alto Douro Wine Region-Evolutive and Living Cultural Landscape-Assessment Report; CCDRN/EMD, CIBIO UP-UTAD: Porto, Portugal, 2013; p. 118.

28. Biagioli, G.; Vezzosi, R. 4. The Agrarian/Rural Organisation of Space, Production and Productivity: Its Characters. In European Guidelines for Wine Cultural Landscape Preservation and Enhancement_With Special Regard to Endangered Areas and Vineyards, Italy; Biagioli, G., Prats, M., Bender, J., Eds.; ViTour: Jacksonville, FL, USA, 2012; pp. 20-27.

29. Havlicek, E. Soil biodiversity and bioindication: From complex thinking to simple acting. Eur. J. Soil Biol. 2012, 49, 80-84. [CrossRef]

30. Villani, M.G.; Allee, L.L.; Díaz, A.; Robbins, P.S. Adaptive strategies of edaphic strategies. Annu. Rev. Entomol. 1999, 44, 233-256. [CrossRef]

31. Gonçalves, F.; Carlos, C.; Aranha, J.; Torres, L. Does habitat heterogeneity affect the diversity of epigaeic arthropods in vineyards? Agric. For. Entomol. 2018, 20, 366-379. [CrossRef]

32. Fauna Europaea 2020. Available online: https:/ / fauna-eu.org (accessed on 28 December 2020).

33. Machado, G.; Pinto-da-Rocha, R.; Giribet, G. What Are Harvestmen? In Harvestmen: The Biology of Opiliones; Pinto-da-Rocha, R., Machado, G., Giribet, G., Eds.; Harvard University Press: Cambridge, MA, USA, 2007; pp. 1-14.

34. Bragagnolo, C.; Nogueira, A.A.; Pinto-da-Rocha, R.; Pardini, R. Harvestmen in an Atlantic forest fragmented landscape: Evaluating assemblage response to habitat quality and quantity. Biol. Conserv. 2007, 139, 389-400. [CrossRef]

35. Gerlach, J.; Samways, M.; Pryke, J. Terrestrial invertebrates as bioindicators: An overview of available taxonomic groups. J. Insect Conserv. 2013, 17, 831-850. [CrossRef] 
36. Pryke, J.S.; Samways, M.J. Recovery of invertebrate diversity in a rehabilitated city landscape mosaic in the heart of a biodiversity hotspot. Landsc. Urban Plan. 2009, 93, 54-62. [CrossRef]

37. Johnson, E.A.; Catley, K.M. Life in the Leaf Litter; Center for Biodiversity and Conservation, American Museum of Natural History: New York, NY, USA, 2002; p. 28.

38. Scorpion. Encyclopædia Britannica, Inc. Available online: https:/ /www.britannica.com/animal/scorpion (accessed on 4 January 2021).

39. Hruskova-Martisova, M.; Pekár, S.; Cardoso, P. Natural history of the Iberian solifuge Gluvia dorsalis (Solifuges: Daesiidae). J. Arachnol. 2010, 38, 466-474. [CrossRef]

40. The Arachnid Order Solifugae. Available online: http:/ / www.solifugae.info/ (accessed on 4 January 2021).

41. González-Moliné, A.L.; Melic, A.; Barrientos, J.A. Taxonomía, distribución geográfica e historia natural del endemismo ibérico Gluvia dorsalis (Latreille, 1817) (Solifugae: Daesiidae). Bol. Soc. Entomol. Aragonesa 2008, 42, 385-395.

42. Dhooria, M.S. Fundamentals of Applied Acarology; Springer: Singapore, 2016; p. 470.

43. Coleman, D.C.; Crossley, D.A., Jr.; Hendrix, P.F. Fundamentals of Soil Ecology, 2nd ed.; Academic Press: Cambridge, MA, USA, 2004.

44. O'Neill, K.P.; Godwin, H.W.; Jimenez-Esquilin, A.E.; Battigelli, J.P. Reducing the dimensionality of soil micro invertebrate community datasets using indicator species analysis: Implications for ecosystem monitoring and soil management. Soil Biol. Biochem. 2010, 42, 145-154. [CrossRef]

45. Jung, M.P.; Kim, S.T.; Kim, H.; Lee, J.H. Species diversity and community structure of ground-dwelling spiders in unpolluted and moderately heavy metal-polluted habitats. Water Air Soil Pollut. 2008, 195, 15-22. [CrossRef]

46. Hoy, M.A. Soil Mites (Acari: Oribatida and Others). In Encyclopedia of Entomology; Capinera, J.L., Ed.; Springer: Dordrecht, Germany, 2008.

47. Wise, D.H.; Snyder, W.E.; Tuntibunpakul, P.; Halaj, J. Spiders in decomposition food webs of agroecosystems: Theory and evidence. J. Arachnol. 1999, 27, 363-370.

48. Marc, P.; Canard, A.; Ysnel, F. Spiders (Araneae) useful for pest limitation and bioindication. Agric. Ecosyst. Environ. 1999, 74, 229-273. [CrossRef]

49. Culin, J.; Levi, H.W.; Levi, L.R. Spider. Available online: https://www.britannica.com/animal/spider-arachnid (accessed on 18 January 2021).

50. Collingwood, C.; Prince, A. A guide to ants of Continental Portugal (Hymenoptera: Formicidae). Bol. Soc. Port. Entomol. $1998,5,1-49$.

51. Pekár, S.; Coddington, J.A.; Blackledge, T.A. Evolution of stenophagy in spiders (Araneae): Evidence based on the comparative analysis of spider diets. Evolution 2012, 66, 776-806. [CrossRef] [PubMed]

52. Ceccarelli, F.S. Ant-mimicking spiders: Strategies for living with social insects. Psyche J. Entomol. 2013, 2013, 839181. [CrossRef]

53. Nelson, X.J.; Jackson, R.R. How spiders practice aggressive and Batesian mimicry. Curr. Zool. 2012, 58, 620-629. [CrossRef]

54. Hölldobler, B.; Wilson, E.O. The Ants; Belknap Press of Harvard University: Cambridge, MA, USA, $1990 ;$ p. 732.

55. Pekár, S. Spiders (Araneae) in the pesticide world: An ecotoxicological review. Pest Manag. Sci. 2012, 68, 1438-1446. [CrossRef]

56. Pfingstmann, A.; Paredes, D.; Buchholz, J.; Querner, P.; Bauer, T.; Strauss, P.; Kratschmer, S.; Winter, S.; Zaller, J. Contrasting effects of tillage and landscape structure on spiders and springtails in vineyards. Sustainability 2019, 11, 2095. [CrossRef]

57. Fiera, C.; Ulrich, W.; Popescu, D.; Bunea, C.J.; Manu, M.; Nae, J.; Stan, M.; Markó, B.; Urák, I.; Giurginca, A.; et al. Effects of vineyard inter-row management on the diversity and abundance of plants and surface-dwelling invertebrates in Central Romania. J. Insect Conserv. 2020, 24, 175-185. [CrossRef]

58. Jiménez-García, L.; García-Martínez, Y.G.; Marco-Mancebón, V.; Pérez-Moreno, I.; Jiménez-García, D. Biodiversity analysis of natural arthropods enemies in vineyard agroecosystems in La Rioja, Spain. J. Asia Pac. Entomol. 2019, 22, 308-315. [CrossRef]

59. Branco, V.V.; Morano, E.; Cardoso, P. An update to the Iberian spider checklist (Araneae). Zootaxa 2019, 4614, 201-225. [CrossRef]

60. Cardoso, P.; Pekár, S.; Jocqué, R.; Coddington, J.A. Global patterns of guild composition and functional diversity of spiders. PLoS ONE 2011, 6, e21710. [CrossRef] [PubMed]

61. Pekár, S.; Toft, S. Can ant-eating Zodarion spiders (Araneae: Zodariidae) develop on a diet optimal for euryphagous arthropod predators? Physiol. Entomol. 2009, 34, 195-201. [CrossRef]

62. Cushing, P.E. Myrmecomorphy and myrmecophily in spiders: A review. Fla. Entomol. 1997, 80, 165-193. [CrossRef]

63. Pekár, S.; Smerda, J.; Hrušková, M.; Sedo, O.; Muster, C.; Cardoso, P.; Zdráhal, Z.; Korenko, S.; Bureš, P.; Líznarová, E.; et al. Prey-race drives differentiation of biotypes in ant-eating spiders. J. Anim. Ecol. 2012, 81, 838-848. [CrossRef] [PubMed]

64. Řezáč, M.; Pekár, S.; Lubin, Y. How oniscophagous spiders overcome woodlouse armour. J. Zool. 2008, 275, 64-71. [CrossRef]

65. Smrž, J.; Kováč, L.; Mikeš, J.; Lukešová, A. Microwhip scorpions (Palpigradi) feed on heterotrophic cyanobacteria in Slovak caves-A curiosity among Arachnida. PLoS ONE 2013, 8, e75989. [CrossRef]

66. Friend, J.A.; Richardson, A.M.M. Biology of Terrestrial Amphipods. Ann. Rev. Entomol. 1986, 31, 25-48. [CrossRef]

67. Duncan, K.W. Terrestrial Talitridae (Crustacea: Amphipoda). In Fauna of New Zealand; Manaaki Whenua Press: Lincoln, New Zealand, 1994; Volume 31, p. 128.

68. Fialkowski, W.; Rainbow, P.S.; Fialkowska, E.; Smith, B.D. Biomonitoring of trace metals along the Baltic Coast of Poland using the sandhopper Talitrus saltator (Montagu) (Crustacea: Amphipoda). Ophelia 2000, 52, 183-192. [CrossRef]

69. Bagyaraj, D.J.; Nethravathi, C.J.; Nitin, K.S. Soil Biodiversity and Arthropods: Role in Soil Fertility. In Economic and Ecological Significance of Arthropods in Diversified Ecosystems; Chakravarthy, A.K., Sridhara, S., Eds.; Springer: Singapore, 2016.

70. Souty-Grosset, C.; Faberi, A. Effect of agricultural practices on terrestrial isopods: A review. ZooKeys 2018, 801, 63-96. [CrossRef] 
71. Solomou, A.D.; Sfugaris, A.I.; Sfenthourakis, S. Terrestrial isopods as bioindicators for environmental monitoring in olive groves and natural ecosystems. J. Nat. Hist. 2019, 53, 1721-1735. [CrossRef]

72. Drobne, D.; Blazic, M.; Van Gestel, C.A.; Leser, V.; Zidar, P.; Jemec, A.; Trebse, P. Toxicity of imidacloprid to the terrestrial isopod Porcellio scaber (Isopoda, Crustacea). Chemosphere 2008, 71, 1326-1334. [CrossRef] [PubMed]

73. Van Gestel, C.A.M.; Loureiro, S.; Zidar, P. Terrestrial isopods as model organisms in soil ecotoxicology: A review. ZooKeys 2018, 801, 127-162. [CrossRef]

74. Blanusa, M.; Mrkovich-Milic, R.; Durbesic, P. Lead and cadmium in soil and Isopoda Woodlice in Croatia. Ecotox. Environ. Saf. 2002, 52, 198-202. [CrossRef]

75. Paoletti, M.G.; Hassall, M. Woodlice (Isopoda: Oniscidea): Their potential for assessing sustainability and use as bioindicators. Agric. Ecosyst. Environ. 1999, 74, 157-165. [CrossRef]

76. Romoser, W.S.; Stoffolano, J.G., Jr. The Science of Entomology, 3rd ed.; WMC Brown Communications Inc.: Dubuque, IA, USA, 1994.

77. Hopkin, S.P. Biology of the Springtails (Insecta: Collembola); Oxford University Press: Oxford, UK, 1997; p. 330.

78. Filser, J. The role of Collembola in carbon and nitrogen cycling in soil. Pedobiologia 2002, 46, 234-245. [CrossRef]

79. Rusek, J. Biodiversity of Collembola and their functional role in the ecosystem. Biodivers. Conserv. 1998, 7, 1207-1219. [CrossRef]

80. Christiansen, K.A.; Bellinger, P.; Janssens, F. Collembola: (Springtails, Snow Fleas). In Encyclopedia of Insects, 2nd ed.; Resh, V.H., Cardé, R.T., Eds.; Academic Press: San Diego, CA, USA, 2009; pp. 206-210.

81. Ponge, J.F. Utilisation de la micromorphologie pour l'étude des relations trophiques dans le sol: La couche L d'un moder hydromorphe sous Pinus sylvestris (Forêt d'Orléans, France). Bull. Ecol. 1985, 16, 117-132.

82. Orgiazzi, A.; Bardgett, R.D.; Barrios, E.; Behan-Pelletier, V.; Briones, M.J.I.; Chotte, J.-L.; De Deyn, G.B.; Eggleton, P.; Fierer, N.; Fraser, T.; et al. Global Soil Biodiversity Atlas; European Commission, Publications Office of the European Union: Luxembourg, 2016; p. 176.

83. Greenslade, P.; Boyer, S.; Shields, M.W.; Wratten, S.D. First record of a possible predatory collembolan species, Dicyrtoma fusca (Collembola: Dicyrtomidae), in New Zealand. Austral. Entomol. 2016, 56, 332-338. [CrossRef]

84. Chernova, N.M.; Kuznetsova, N.A. Collembolan community organization and its temporal predictability. Pedobiologia 2000, 44, 451-466. [CrossRef]

85. Arbea, J.I.; Blasco-Zumeta, J. Ecología de los Colémbolos (Hexapoda, Collembola) en Los Monegros (Zaragoza, España). Bol. Soc. Entomol. Aragonesa 2001, 28, 35-48.

86. Detsis, V. Vertical distribution of Collembola in deciduous forests under Mediterranean climatic conditions. Belg. J. Zool. 2000, $130,57-61$.

87. Yadav, R.S.; Kerketta, D.; Kumar, D.; Prasad, S. Vertical Distribution of Collembola (Arthropoda: Collembola) at Varanasi, India. Int. J. Curr. Microbiol. Appl. Sci. 2018, 7, 609-613. [CrossRef]

88. Yin, R.; Gruss, I.; Eisenhauer, N.; Kardol, P.; Thakur, M.P.; Schmidt, A.; Xu, Z.; Siebert, J.; Zhang, C.; Wu, G.L.; et al. Land use modulates the effects of climate change on density but not community composition of Collembola. Soil Biol. Biochem. 2019, 138, 107598. [CrossRef]

89. Yin, R.; Kardol, P.; Thakur, M.P.; Gruss, I.; Wu, G.L.; Eisenhauer, N.; Schädler, M. Soil functional biodiversity and biological quality under threat: Intensive land use outweighs climate change. Soil Biol. Biochem. 2020, 147, 107847. [CrossRef] [PubMed]

90. Fountain, M.T.; Hopkin, S.P. Biodiversity of Collembola in urban soils and the use of Folsomia candida to assess soil 'quality'. Ecotoxicology 2004, 13, 555-572. [CrossRef]

91. An, Y.-J.; Kim, S.W.; Lee, W.-M. The collembola Lobella sokamensis juvenile as a new soil quality indicator of heavy metal pollution. Ecol. Indic. 2013, 27, 56-60. [CrossRef]

92. Zhu, D.; Chen, Q.-L.; An, X.L.; Yang, X.-R.; Christie, P.; Ke, X.; Wu, L.-H.; Zhu, Y.-G. Exposure of soil collembolans to microplastics perturbs their gut microbiota and alters their isotopic composition. Soil Biol. Biochem. 2018, 116, 302-310. [CrossRef]

93. Frampton, G.K. The potential of Collembola as indicators of pesticide usage: Evidence and methods from the UK arable ecosystem. Pedobiologia 1997, 41, 179-184.

94. Fiera, C.; Ulrich, W.; Popescu, D.; Buchholz, J.; Querner, P.; Bunea, C.-I.; Strauss, P.; Bauer, T.; Kratschmer, S.; Winter, S.; et al. Tillage intensity and herbicide application influence surface-active springtail (Collembola) communities in Romanian vineyards. Agric. Ecosyst. Environ. 2020, 300, 107006. [CrossRef]

95. Sterzynska, M.; Nicia, P.; Zadrozny, P.; Fiera, C.; Shrubovych, J.; Ulrich, W. Urban springtail species richness decreases with increasing air pollution. Ecol. Indic. 2018, 94, 328-335. [CrossRef]

96. Sendra, A.; Jiménez-Valverde, A.; Selfa, J.; Reboleira, A.S.P.S. Diversity, ecology, distribution and biogeography of Diplura. Insect Conserv. Divers. 2021, 14, 415-425. [CrossRef]

97. Bachelier, G. La Vie Animale Dans les Sols; ORSTOM: Paris, France, 1963; p. 279.

98. Beutel, R.G.; Friedrich, F.; Ge, S.-Q.; Yang, X.-K. Insect Morphology and Phylogeny: A Textbook for Students of Entomology; De Gruyter: Berlin, Germany, 2014; p. 516.

99. Pass, G.; Szucsich, N.U. 100 years of research on the Protura: Many secrets still retained. Soil Org. 2011, 83, 309-334.

100. Galli, L.; Capurro, M.; Molyneux, T.; Torti, C.; Zinni, M. Ecology of Italian Protura. Pedobiol. J. Soil Ecol. 2019, 73, 20-28. [CrossRef]

101. Malmström, A.; Persson, T. Responses of Collembola and Protura to tree girdling-Some support for ectomycorrhizal feeding. Soil Org. 2011, 83, 279-285. 
102. Bluhm, S.L.; Potapov, A.M.; Shrubovych, J.; Ammerschubert, S.; Polle, A.; Scheu, S. Protura are unique: First evidence of specialized feeding on ectomycorrhizal fungi in soil invertebrates. BMC Ecol. 2019, 19, 10. [CrossRef]

103. Christian, E.; Szeptycki, A. Distribution of Protura along an urban gradient in Vienna. Pedobiologia 2004, 48, 445-452. [CrossRef]

104. Nakamura, O. Habitat preference of species of the family Eosentomidae (Hexapoda: Protura) in Kanto district, central Japan. Bull. Saitama Mus. Nat. Hist. 2014, 8, 15-18.

105. Triplehorn, C.A.; Johnson, N.F. Borror and DeLong's Introduction to the Study of Insects, 7th ed.; Thomson Brooks/Cole: Belmont, CA, USA, 2005.

106. Ghannem, S.; Touaylia, S.; Boumaiza, M. Beetles (Insecta: Coleoptera) as bioindicators of the assessment of environmental pollution. Hum. Ecol. Risk Assess. 2018, 24, 456-464. [CrossRef]

107. Lövei, G.L.; Sunderland, K.D. Ecology and behavior of ground beetles (Coleoptera: Carabidae). Annu. Rev. Entomol. 1996, 41, 231-256. [CrossRef]

108. Holland, J.M.; Luff, M.L. The effects of agricultural practices on Carabidae in temperate agroecosystems. Integr. Pest. Manag. Rev. 2000, 5, 109-129. [CrossRef]

109. Gailis, J.; Turka, I. Discussion on ground beetles and rove beetles as indicators of sustainable agriculture in Latvia: Review. Res. Rural Dev. 2013, 1, 56-62.

110. Kotze, D.J.; Brandmayr, P.; Casale, A.; Dauffy-Richard, E.; Dekoninck, W.; Koivula, M.J.; Lövei, G.L.; Mossakowski, D.; Noordijk, J.; Paarmann, W.; et al. Forty years of carabid beetle research in Europe-from taxonomy, biology, ecology and population studies to bioindication, habitat assessment and conservation. Zookeys 2011, 100, 55-148. [CrossRef]

111. Niemelä, J. Carabid beetles (Coleóptera: Carabidae) and habitat fragmentation: A review. Eur. J. Entomol. 2001, 98, 127-132. [CrossRef]

112. Tőzsér, D.; Magura, T.; Simon, E.; Mizser, S.; Papp, D.; Tóthmérész, B. Pollution intensity-dependent metal accumulation in ground beetles: A meta-analysis. Environ. Sci. Pollut. Res. 2019, 26, 32092-32102. [CrossRef]

113. Rainio, J.; Niemelä, J. Ground beetles (Coleoptera: Carabidae) as bioindicators. Biodivers. Conserv. 2003, 12, 487-506. [CrossRef]

114. Avgın, S.S.; Luff, M.L. Ground beetles (Coleoptera: Carabidae) as bioindicators of human impact. Munis Entomol. Zool. 2010, 5, 209-215.

115. Butovsky, R.O. Heavy metals in carabids (Coleoptera, Carabidae). Zookeys 2011, 100, 215-222. [CrossRef]

116. Jiménez-Valverde, A.; Ortuño, V.M. The history of endemic Iberian ground beetle description (Insecta, Coleoptera, Carabidae): Which species were described first? Acta Oecol. 2007, 31, 13-31. [CrossRef]

117. Mifsud, D. Altica ampelophaga Guerin-Meneville, 1858-new record of Flea Beetle for Malta (Coleoptera, Chrysomelidae). Bull. Entomol. Soc. Malta 2012, 5, 185-187.

118. El-Torkey, A.M.; Oshaibah, A.D.A.; Salem, M.M.H.; Hossni, M.T.; El-Zouk, A.A.A. Soft winged flower beetles (Coleoptera: Malachiidae) in Egypt. Bol. Soc. Entomol. Aragonesa 2012, 50, 285-294.

119. Yildirim, E.; Bulak, Y. A contribution to the knowledge of the Malachiidae (Coleoptera: Cleroidea) fauna of Turkey. Türk. Entomol. Derg. 2012, 36, 231-238.

120. Yavorskaya, M.I.; Leschen, R.A.B.; Polilov, A.A.; Beutel, R.G. Unique rostrate larvae and basidiomycophagy in the beetle family Corylophidae. Arthropod Struct. Dev. 2014, 43, 153-162. [CrossRef]

121. Wagner, T. Influence of forest type and tree species on canopy-dwelling beetles in Budongo Forest, Uganda. Biotropica 2000, 32, 502-514. [CrossRef]

122. Lord, N.P.; Hartley, C.S.; Lawrence, J.F.; Mchugh, J.V.; Whiting, M.F.; Miller, K.B. Phylogenetic analysis of the minute brown scavenger beetles (Coleoptera: Latridiidae), and recognition of a new beetle family, Akalyptoischiidae fam.n. (Coleoptera: Cucujoidea). Syst. Entomol. 2010, 35, 753-763. [CrossRef]

123. Gimmel, M.L.; Aston, P. New records of the family Phalacridae from Hong Kong (Coleoptera: Cucujoidea). Hong Kong Entomol. Soc. 2010, 2, 11-12.

124. Sousa, W.O.; Ribeiro-Costa, C.S.; Rosado-Neto, G.H. A preliminary overview of the Brazilian Apioninae (Coleoptera: Brentidae) with an illustrated key for genera, and a checklist with distribution information. Biota Neotrop. 2019, 19, e20190813. [CrossRef]

125. Shah, F.A.; Ansari, M.A.; Prasad, M.; Butt, T.M. Evaluation of black vine weevil (Otiorhynchus sulcatus) control strategies using Metarhizium anisopliae with sublethal doses of insecticides in disparate horticultural growing media. Biol. Control 2007, 40, 246-252. [CrossRef]

126. Alekseev, V.I.; Grzymala, T.L. New Aderidae (Coleoptera: Tenebrionoidea) from Baltic and Bitterfeld amber. Zootaxa 2015, 3956, 239-257. [CrossRef]

127. Werner, F.G.; Chandler, D.S. Anthicidae (Insecta: Coleoptera). Fauna New Zeal. 1995, 34, 1-64.

128. Bologna, M.A.; Pinto, J.D. The Old World genera of Meloidae (Coleoptera): A key and synopsis. J. Nat. Hist. 2002, 36, 2013-2102. [CrossRef]

129. Pinto, J.D.; Bologna, M.A. Beetles (Coleoptera) of Peru. Survey of the Families. Meloidae Gyllenhal, 1810. J. Kansas Entomol. Soc. 2016, 89, 202-209. [CrossRef]

130. Sánches-Vialas, A.; García-París, M.; Ruiz, J.L.; Recuero, E. Patterns of morphological diversification in giant Berberomeloe blister beetles (Coleoptera: Meloidae) reveal an unexpected taxonomic diversity concordant with mtDNA phylogenetic structure. Zool. J. Linn. Soc. 2020, 189, 1249-1312. [CrossRef]

131. Michaels, K.F. Using staphylinid and tenebrionid beetles as indicators of sustainable landscape management in Australia: A review. Aust. J. Exp. Agric. 2007, 47, 435-449. [CrossRef] 
132. Ocete, R.; Armendáriz, I.; Ocete, C.A.; Maistrello, L.; Valle, J.A.; Rodríguez, A.; Usategui, L. Spread parameters of the borer Xylotrechus arvicola (Olivier) (Coleoptera: Cerambicidae) in a 'Tempranillo' Vineyard in la Rioja (Spain): A long-term study. Ciênc. Téc. Vitiv. 2020, 35, 148-166. [CrossRef]

133. Kozlov, M.V.; Prosvirov, A.S.; Zvereva, E.L. Can larvae of forest click beetles (Coleoptera: Elateridae) feed on live plant roots? Insects 2020, 11, 850. [CrossRef] [PubMed]

134. Vuts, J.; Imrei, Z.; Birkett, M.A.; Pickett, J.A.; Woodcock, C.M.; Tóth, M. Semiochemistry of the Scarabaeoidea. J. Chem. Ecol. 2014, 40, 190-210. [CrossRef]

135. Kurbatov, S.A.; Egorov, L.V. Review of the fauna of the beetle families Scydmaenidae and Pselaphidae (Coleoptera, Staphylinoidea) of Chuvashia. Entomol. Rev. 2012, 92, 864-878. [CrossRef]

136. Newton, A.F.; Franz, H. World catalog of the genera of Scydmaenidae (Coleoptera). Koleopterol. Rundsch. 1998, 68, $137-165$.

137. López-Pérez, J.J. NOTA NOTE—Corología de Palaeostigus palpalis (Latreille, 1804) (Coleoptera, Staphylinoidea, Scydmaenidae) en la provincia de Huelva (S.O. de Andalucía, España). Arq. Entomolóxicos 2015, 13, 145-148.

138. Frank, J.H.; Thomas, M.C. Rove beetles of the World, Staphylinidae (Insecta: Coleoptera: Staphylinidae). Entomology and Nematology Department, UF/IFAS Extension. 2016. Available online: https://edis.ifas.ufl.edu/publication/IN271 (accessed on 12 July 2021).

139. Bohac, J. Staphylinid beetles as bioindicators. Agric. Ecosyst. Environ. 1999, 74, 357-372. [CrossRef]

140. Klimaszewski, J.; Crosby, T.K. A revision of the New Zealand species of the parasitoid genus Aleochara, with description of four new species (Coleoptera: Staphylinidae). J. R. Soc. N. Z. 1997, 27, 243-269. [CrossRef]

141. Klimaszewski, J.; Pace, R.; Center, T.D.; Couture, J. A remarkable new species of Himalusa pace from Thailand (Coleoptera, Staphylinidae, Aleocharinae): Phytophagous aleocharine beetle with potential for biocontrol of skunkvine-related weeds in the United States. ZooKeys 2010, 35, 1-12. [CrossRef]

142. Marcelino, J.A.P.; Giordano, R.; Borges, P.A.V.; Garcia, P.V.; Soto-Adames, F.N.; Soares, A.O. Distribution and genetic variability of Staphylinidae across a gradient of anthropogenically influenced insular landscapes. Bull. Insectology 2016, 69, 117-126.

143. Weithmann, S.; Kuppler, J.; Degasperi, G.; Steiger, S.; Ayasse, M.; von Hoermann, C. Local and landscape effects on carrionassociated rove beetle (Coleoptera: Staphylinidae) Communities in German Forests. Insects 2020, 11, 828. [CrossRef]

144. Lupi, D.; Colombo, M.; Zanetti, A. The rove beetles (Coleoptera Staphylinidae) of three horticultural farms in Lombardy (Northern Italy). Boll. Zool. Agr. Bachic. 2006, 38, 143-165.

145. Donovan, S.; Eggleton, P.; Bignell, D. Gut content analysis and a new feeding group classification of termites. Ecol. Entomol. 2001, 26, 356-366. [CrossRef]

146. Bourguignon, T.; Sobotník, J.; Lepoint, G.; Martin, J.-M.; Hardy, O.J.; Ean, A.D.; Roiin, Y. Feeding ecology and phylogenetic structure of a complex neotropical termite assemblage, revealed by nitrogen stable isotope ratios. Ecol. Entomol. 2011, 36, 261-269. [CrossRef]

147. Jouquet, P.; Chaudhary, E.; Kumar, A.R.V. Sustainable use of termite activity in agro-ecosystems with reference to earthworms. A review. Agron. Sustain. Dev. 2018, 38, 3. [CrossRef]

148. Eggleton, P.; Bignell, D.E.; Hauser, S.; Dibog, L.; Norgrove, L.; Madong, B. Termite diversity across an anthropogenic disturbance gradient in the humid forest zone of West Africa. Agric. Ecosyst. Environ. 2002, 90, 189-202. [CrossRef]

149. Jones, D.T.; Susilo, F.X.; Bignell, D.E.; Hardiwinoto, S.; Gillison, A.N.; Eggleton, P. Termite assemblage collapse along a land-use intensification gradient in lowland central Sumatra, Indonesia. J. Appl. Ecol. 2003, 40, 380-391. [CrossRef]

150. Pribadi, T. Termites community as environmental bioindicators in highlands: A case study in eastern slopes of Mount Slamet, Central Java. Biodivers. J. Biol. Divers. 2011, 12, 235-240. [CrossRef]

151. Viana-Junior, A.B.; Souza, V.B.; Reis, Y.T.; Marques-Costa, A.P. Termite assemblages in dry tropical forests of Northeastern Brazil: Are termites bioindicators of environmental disturbances? Sociobiology 2014, 61, 324-331. [CrossRef]

152. Frouz, J. Use of soil dwelling Diptera (Insecta, Diptera) as bioindicators: A review of ecological requirements and response to disturbance. Agric. Ecosyst. Environ. 1999, 74, 167-186. [CrossRef]

153. McMillan, D.; Hohu, K.; Edgerly, J.S. Choreography of silk spinning by webspinners (Insecta: Embioptera) reflects lifestyle and hints at phylogeny. Biol. J. Linn. Soc. 2016, 118, 430-442. [CrossRef]

154. Gullan, P.J.; Cranston, P.S. The Insects: An Outline of Entomology, 5th ed.; Wiley-Blackwell: West Sussex, UK, $2014 ;$ p. 624.

155. Song, Z.-S.; Bartlett, C.R.; O’Brien, L.B.; Liang, A.P.; Bourgoin, T. Morphological phylogeny of Dictyopharidae (Hemiptera: Fulgoromorpha). Syst. Entomol. 2018, 43, 637-658. [CrossRef]

156. Carlos, C.C.R. Towards a Sustainable Control of Arthropod Pests in Douro Demarcated Region Vineyards with Emphasis on the Grape Berry Moth, Lobesia botrana (Denis \& Schifermüller). Ph.D. Thesis, University of Trás-os-Montes and Alto Douro, Vila Real, Portugal, 2017.

157. Krstić, O.; Cvrković, T.; Mitrović, M.; Toševski, I.; Jović, J. Dictyophara europaea (Hemiptera: Fulgoromorpha: Dictyopharidae): Description of immatures, biology and host plant associations. Bull. Entomol. Res. 2016, 106, 395-405. [CrossRef]

158. Schwertner, C.F.; Nardi, C. Burrower Bugs (Cydnidae). In True Bugs (Heteroptera) of the Neotropics. Entomology in Focus; Panizzi, A., Grazia, J., Eds.; Springer: Dordrecht, Germany, 2015; Volume 2.

159. Henry, T.J. Biodiversity of Heteroptera. In Insect Biodiversity: Science and Society, 2nd ed.; Foottit, R.G., Adler, P.H., Eds.; John Wiley \& Sons Ltd.: New Jersey, NJ, USA, 2017; Volume I, pp. 279-335. 
160. Henry, T.J.; Dellapé, P.M.; de Paula, A.S. The Big-Eyed Bugs, Chinch Bugs, and Seed Bugs (Lygaeoidea). In True Bugs (Heteroptera) of the Neotropics. Entomology in Focus; Panizzi, A., Grazia, J., Eds.; Springer: Dordrecht, Germany, 2015; Volume 2, pp. $154-196$.

161. Koch, R.L.; Pezzini, D.T.; Michel, A.P.; Hunt, T.E. Identification, biology, impacts, and management of stink bugs (Hemiptera: Heteroptera: Pentatomidae) of soybean and corn in the Midwestern United States. J. Integr. Pest. Manag. 2017, 8, 1-14. [CrossRef]

162. Taylor, M.E.; Bundy, C.S.; Mcpheron, J.E. Unusual Ovipositional Behavior of the Stink Bug Bagrada hilaris (Hemiptera: Heteroptera: Pentatomidae). Ann. Entomol. Soc. Am. 2014, 107, 872-877. [CrossRef]

163. Fowles, T.M.; Coscarón, M.C.; Panizzi, A.R.; Carroll, S.P. Scentless Plant Bugs (Rhopalidae). In True Bugs (Heteroptera) of the Neotropics. Entomology in Focus; Panizzi, A., Grazia, J., Eds.; Springer: Dordrecht, Germany, 2015; Volume 2, pp. $607-637$.

164. Panizzi, A.R.; Hirose, E.; Chocorosqui, V.R. Unusual Oviposition Behavior by a Seed Feeding Bug (Heteroptera: Rhopalidae). Scientific Note. Neotrop. Entomol. 2002, 31, 477-479. [CrossRef]

165. Wu, Y.-Z.; Rédei, D.; Eger, J., Jr.; Wang, Y.-H.; Wu, H.-Y.; Carapezza, A.; Kment., P.; Cai, B.; Sun, X.-Y.; Guo, P.-L.; et al. Phylogeny and the colourful history of jewel bugs (Insecta: Hemiptera: Scutelleridae). Cladistics 2018, 34, 502-516. [CrossRef]

166. Rasplus, J.-Y.; Villemant, C.; Paiva, M.R.; Delvare, G.; Roques, A. Hymenoptera. Chapter 12. BioRisk 2010, 4, 669-776. [CrossRef]

167. Guglielmino, A. Dryinidae (Hymenoptera Chrysidoidea): An interesting group among the natural enemies of the Auchenorrhyncha (Hemiptera). Denisia 2002, 4, 549-556.

168. Macek, J. Chrysidoidea: Dryinidae (Lapkovití) and Embolemidae (Vejřenkovití). In Annotated checklist of the Aculeata (Hymenoptera) of the Czech Republic and Slovakia; Bogusch, P., Straka, J., Kment, P., Eds.; Acta Entomologica Musei Nationalis Pragae Supplementum: Prague, Czech Republic, 2007; pp. 65-84.

169. Cerdá, X.; Dejean, A. Predation by Ants on Arthropods and Other Animals. Predation in the Hymenoptera: In An Evolutionary Perspective; Polidori, C., Ed.; Transworld Research Network: Kerala, India, 2011; pp. 39-78.

170. Karhu, K.J. Effects of ant exclusion during outbreaks of a defoliator and a sap-sucker on birch. Ecol. Entomol. 1998, 23, 185-194. [CrossRef]

171. Albert, M.J.; Escudero, A.; Iriondo, J.M. Assessing ant seed predation in threatened plants: A case study. Acta Oecol. 2005, 28, 213-220. [CrossRef]

172. Rodriguez, J.; Calle, Z.; Montoya-Lerma, J. Herbivory of Atta cephalotes (Hymenoptera: Myrmicinae) on three plant substrates. Rev. Colomb. Entomol. 2008, 34, 156-162.

173. Baraibar, B.; Torra, J.; Royo-Esnal, A.; Recasens, J.; Comas, C. Harvester ant nest distribution depends on soil disturbance regime. Biol. Control. 2019, 128, 1-5. [CrossRef]

174. Perez, J.E.J.; Dupo, A.L.A.B. Arthropod community structure during the early stages of leaf litter decomposition. Asian J. Biodiv. 2013, 4, 84-98. [CrossRef]

175. Detrain, C.; Verheggen, F.J.; Diez, L.; Wathelet, B.; Haubruge, E. Aphid-ant mutualism: How honeydew sugars influence the behaviour of ant scouts. Physiol. Entomol. 2010, 35, 168-174. [CrossRef]

176. Urbani, C.B.; de Andrade, M.L. Pollen eating, storing, and spitting by ants. Naturwissenschaften 1997, 84, 256-258. [CrossRef]

177. Kost, C.; Heil, M. Increased availability of extrafloral nectar reduces herbivory in Lima bean planted (Phaseolus lunatus, Fabaceae). Basic App. Ecol. 2005, 6, 237-248. [CrossRef]

178. Stefani, V.; Pires, T.; Torezan-Silingardi, H.M.; Del Claro, K. Beneficial effects of ants and spiders on the reproductive value of Eriotheca gracilipes (Malvaceae) in a Tropical Savanna. PLoS ONE 2015, 10, 1-12. [CrossRef] [PubMed]

179. Del-Claro, K.; Rico-Gray, V.; Torezan-Silingardi, H.M.; Alves-Silva, E.; Fagundes, R.; Lange, D.; Dáttilo, W.; Vilela, A.A.; Aguirre, A.; Rodriguez-Morales, D. Loss and gains in ant-plant interactions mediated by extrafloral nectar: Fidelity, cheats, and lies. Insectes Soc. 2016, 63, 207-221. [CrossRef]

180. Majer, J.D. Ants: Bio-indicators of mine site rehabilitation, land-use, and land conservation. Environ. Manag. 1993, 7, 375-383. [CrossRef]

181. Casimiro, M.S.; Sansevero, J.B.B.; Queiroz, J.M. What can ants tell us about ecological restoration? A global meta-analysis. Ecol. Indic. 2019, 102, 593-598. [CrossRef]

182. Andersen, A.N.; Majer, J.D. Ants show the way down under: Invertebrates as bioindicators in land management. Front. Ecol. Environ. 2004, 2, 291-298. [CrossRef]

183. Bogusch, P. Vespoidea: Mutillidae (Kodulkovití). In Annotated Checklist of the Aculeata (Hymenoptera) of the Czech Republic and Slovakia; Bogusch, P., Straka, J., Kment, P., Eds.; Acta Entomologica Musei Nationalis Pragae Supplementum: Prague, Czech Republic, 2007; pp. 93-104.

184. Brothers, D.J. Alternative Life-History Styles of Mutillid Wasps (Insecta, Hymenoptera). In Alternative Life-History Styles of Animals; Bruton, M.N., Ed.; Kluwer Academic Publishers: Dordrecht, The Netherlands, 1989; pp. 279-291.

185. Luz, D.R.; Rosa, B.B.; Williams, K.A.; Melo, G.A.R. An uncommon feeding habit: Mutillid wasps (Hymenoptera, Mutillidae) visiting extrafloral nectaries in Malpighiaceae. Braz. J. Biol. 2016, 76, 551-553. [CrossRef]

186. Bidau, C. Patterns in Orthoptera biodiversity. I. Adaptations in ecological and evolutionary contexts. J. Insect Biodiv. 2014, 2, 1-39. [CrossRef]

187. Whitman, D.W.; Richardson, M.L. Necrophagy in grasshoppers: Taeniopoda eques feeds on mammal carrion. J. Orthoptera Res. 2010, 19, 377-380. [CrossRef]

188. Capinera, J.L.; Sechrist, T.S. Grasshoppers (Acrididae) of Colorado: Identification, biology and management. Colo. State Univ. Exp. Stn. Collin Bull. 1982, 584, 1-161.

189. López-Colón, J.I. Sciobia lusitanica Rambur, 1839, grillo endémico del área ibero-marroquí (Orthoptera, Gryllidae, Sciobiinae). Bol. Soc. Entomol. Aragonesa 2001, 28, 66. 
190. Miranda-Arabolaza, M.J.; Barranco, P. Os ortópteros da bacia do rio Sabor (Trás-os-Montes e Alto Douro, Portugal) (Insecta, Orthoptera). Bol. Soc. Entomol. Aragonesa 2005, 37, 173-200.

191. Pérez-Bote, J.L.; Castaño, A.J.R.; Sanromán, J.M.T.; Jiménez, J.M.G. Nuevas citas de Sciobia lusitanica (Rambur, 1839) (Orthoptera, Gryllidae, Gryllinae) en Extremadura (Suroeste de la Península Ibérica). Bol. Soc. Entomol. Aragonesa 2006, 38, $290-291$.

192. Xu, Y.; Held, D.W.; Hu, X.P. Dietary choices and their implication for survival and development of omnivorous mole crickets (Orthoptera: Gryllotalpidae). App. Soil Ecol. 2013, 71, 65-71. [CrossRef]

193. Bailey, D.L.; Held, D.W.; Kalra, A.; Twarakavi, N.; Arriaga, F. Biopores from mole crickets (Scapteriscus spp.) increase soil hydraulic conductivity and infiltration rates. Appl. Soil Ecol. 2015, 94, 7-14. [CrossRef]

194. New, T.R. Neuroptera (Lacewings). In Insects of Australia; CSIRO, Ed.; Cornell University Press: Ithaca, NY, USA, 1991; Volume 2, pp. 525-542.

195. Tauber, C.A.; Tauber, M.J.; Albuquerque, G.S. Neuroptera: (Lacewings, Antlions). In Encyclopedia of Insects, 2nd ed.; Resh, V.H., Cardé, R.T., Eds.; Academic Press: San Diego, CA, USA, 2009; pp. 695-707.

196. Mound, L.A. Thysanoptera: Diversity and Interactions. Annu. Rev. Entomol. 2005, 50, 247-269. [CrossRef] [PubMed]

197. Reynaud, P. Chapter 13.1-Thrips (Thysanoptera). BioRisk 2010, 4, 767-791. [CrossRef]

198. Edgecombe, G.D.; Giribet, G. Evolutionary Biology of Centipedes (Myriapoda: Chilopoda). Annu. Rev. Entomol. 2007, 52, 151-170. [CrossRef]

199. Kula, E.; Lazorik, M. Centipedes, millipedes, terrestrial isopods and their relationships to physical and chemical properties of forest soils. Entomol. Fennica 2016, 27, 33-51. [CrossRef]

200. Lensing, J.R.; Wise, D.H. Predicted climate change alters the indirect effect of predators on an ecosystem process. Proc. Natl. Acad. Sci. USA 2006, 103, 15502-15505. [CrossRef] [PubMed]

201. Wolters, V.; Ekschmitt, K. Gastropods, isopods, diplopods, and chilopods: Neglected groups of the decomposer food web. In Fauna in Soil Ecosystems Recycling Processes, Nutrient Fluxes, and Agricultural Production, 1st ed.; Benckiser, G., Ed.; CRC Press: New York, NY, USA, 1997; pp. 265-306.

202. Ferlian, O.; Scheu, S.; Pollierer, M.M. Trophic interactions in centipedes (Chilopoda, Myriapoda) as indicated by fatty acid patterns: Variations with life stage, forest age and season. Soil Biol. Biochem. 2012, 52, 33-42. [CrossRef]

203. Tuf, I.H.; Tufová, J. Proposal of ecological classification of centipede, millipede and terrestrial isopod faunas for evaluation of habitat quality in Czech Republic. Cas. Slez. Muz. Opava 2008, 57, 37-44.

204. Scheu, S.; Poser, G. The soil macrofauna (Diplopoda, Isopoda, Lumbricidae and Chilopoda) near tree trunks in a beechwood on limestone: Indications for stemfow induced changes in community structure. Appl. Soil Ecol. 1996, 3, 115-125. [CrossRef]

205. Blackburn, J.; Arthur, W. Comparative abundance of centipedes on organic and conventional farms, and its possible relation to declines in farmland bird populations. Basic Appl. Ecol. 2001, 2, 373-381. [CrossRef]

206. Klarner, B.; Winkelmann, H.; Krashevska, V.; Maraun, M.; Widyastuti, R.; Scheu, S. Trophic niches, diversity and community composition of invertebrate top predators (Chilopoda) as affected by conversion of tropical lowland rainforest in Sumatra (Indonesia). PLOS ONE 2017, 12, e0180915.

207. Read, H.; Martin, M.H.; Rayner, J.M.V. Invertebrates in woodlands polluted by heavy metals. An evaluation using canonical correspondence analysis. Water Air Soil Pollut. 1998, 106, 17-42. [CrossRef]

208. De Godoy, J.A.P.; Fontanetti, C.S. Diplopods as Bioindicators of Soils: Analysis of Midgut of Individuals Maintained in Substract Containing Sewage Sludge. Water Air Soil Pollut. 2010, 210, 389-398. [CrossRef]

209. Redi, B.H.; Van Aarde, R.J.; Wassenaar, T.D. Coastal dune forest development and the regeneration of millipede communities. Restor. Ecol. 2005, 13, 284-291. [CrossRef]

210. Scheller, U.; Berg, M.P.; Jansen, M.G.M. Pauropoda (Myriapoda), a class new to the Dutch fauna, with the description of a new species. Entomol. Ber. 2004, 64, 3-9.

211. Scheller, U.; Minor, M. New records of Pauropoda (Myriapoda) from New Zealand with descriptions of four new species and a new family Eirmopauropodidae. N. Z. J. Zool. 2010, 37, 323-337. [CrossRef]

212. Rodriguez, M.T.D. Symphyla y Pauropoda (Myriapoda) de Suelo de España. Ph.D. Thesis, Complutense University of Madrid, Madrid, Spain, 1992.

213. Ochoa-Hueso, R.; Rocha, I.; Stevens, C.J.; Manrique, E.; Luciañez, M.J. Simulated nitrogen deposition affects soil fauna from a semiarid Mediterranean ecosystem in central Spain. Biol. Fertil. Soils 2014, 50, 191-196. [CrossRef]

214. Moritz, L.; Wesener, T. Symphylella patrickmuelleri sp. nov. (Myriapoda: Symphyla): The oldest known Symphyla and first fossil record of Scolopendrellidae from Cretaceous Burmese amber. Cretac. Res. 2018, 84, 258-263. [CrossRef]

215. Camacho, M.D. Phylogeny of the Symphyla (Myriapoda). Ph.D. Thesis, Free University of Berlin, Berlin, Germany, 2009.

216. Langor, D.W.; de Waard, J.R.; Snyder, B.A. Myriapoda of Canada. ZooKeys 2019, 819, 169-186. [CrossRef] [PubMed]

217. Voigtländer, K.; Decker, P.; Burkhardt, U.; Spelda, J. The present knowledge of the Symphyla and Pauropoda (Myriapoda) in Germany-An annotated checklist. Acta Soc. Zool. Bohem. 2016, 80, 51-85.

218. Millennium Ecosystem Assessment. Ecosystems and Human Well-being: Biodiversity Synthesis; World Resources Institute: Washington, DC, USA, 2005.

219. Shackleton, C.M.; Ruwanza, S.; Sinasson Sanni, G.K.; Bennett, S.; De Lacy, P.; Modipa, R.; Mtati, N.; Sachikonye, M.; Thondhlana, G. Unpacking Pandora's box: Understanding and categorising ecosystem disservices for environmental management and human wellbeing. Ecosystems 2016, 19, 587-600. [CrossRef] 
220. Gillespie, M.A.K.; Wratten, S.D. The role of ecosystem disservices in pest management. In Environmental Pest Management: Challenges for Agronomists, Ecologists, Economists and Policymakers; Coll, M., Wajnberg, E., Eds.; John Wiley \& Sons: Oxford, UK, 2017; pp. 175-194.

221. Frouz, J.; Roubíčková, A.; Heděnec, P.; Tajovský, K. Do soil fauna really hasten litter decomposition? A meta-analysis of enclosure studies. Eur. J. Soil Biol. 2015, 68, 18-24. [CrossRef]

222. David, J.F. The role of litter-feeding macroarthropods in decomposition processes: A reappraisal of common views. Soil Biol. Biochem. 2014, 76, 109-118. [CrossRef]

223. Snyder, B.A.; Hendrix, P.F. Current and potential roles of soil macroinvertebrates (earthworms, millipedes, and isopods) in ecological restoration. Rest. Ecol. 2008, 16, 629-636. [CrossRef]

224. Sharma, R.M.; Chandra, K. Insecta: Embioptera. ZooI. Surv. India 2013, 21, 125-126.

225. Noriega, J.A.; Hortal, J.; Azcárate, F.M.; Berg, M.P.; Bonada, N.; Briones, M.J.I.; Toro, I.D.; Goulson, D.; Ibanez, S.; Landis, D.A.; et al. Research trends in ecosystem services provided by insects. Basic Appl. Ecol. 2018, 26, 8-23. [CrossRef]

226. Honek, A.; Martinkova, Z.; Jaroik, V. Ground beetles (Carabidae) as seed predators. Eur. J. Entomol. 2003, 100, 531-544. [CrossRef]

227. Ichihara, M.; Matsuno, K.; Inagaki, H.; Saiki, C.; Mizumoto, S.; Yamaguchi, S.; Yamashita, M.; Sawada, H. Creation of paddy levees to enhance the ecosystem service of weed seed predation by crickets. Landsc. Ecol. Eng. 2015, 11, 227-233. [CrossRef]

228. Blubaugh, C.K.; Hagler, J.R.; Machtley, S.A.; Kaplan, I. Cover crops increase foraging activity of omnivorous predators in seed patches and facilitate weed biological control. Agric. Ecosyst. Environ. 2016, 231, 264-270. [CrossRef]

229. Kendall, D.A. Soil Tillage and Epigeal Predatory Insects. In Soil Tillage in Soil Agroecosystems; El Titi, A., Ed.; CRC Press: Boca Raton, FL, USA, 2003; pp. 297-342.

230. Hoffmann, C.; Köckerling, J.; Biancu, S.; Gramm, T.; Michl, G.; Entling, M.H. Can flowering greencover crops promote biological control in German vineyards. Insects 2017, 8, 121. [CrossRef] [PubMed]

231. Roltsch, W.R.; Hanna, F.; Zalom, H.; Shorey, H.; Mayse, M. Spiders and Vineyard Habitat Relationship in Central California. In Enhancing Natural Control of Arthropods Through Habitat Management; Pickett, C., Bugg, R., Eds.; University of California Press: Berkeley, CA, USA, 1998; pp. 311-338.

232. Pétremand, G.; Fleury, D.; Castella, E.; Delabays, N. Influence de l'enherbement viticole sur les Carabidae (Coleoptera) et intérêt potentiel pour le contrôle de certains ravageurs de la vigne. Biotechnol. Agron. Soc. Environ. 2016, 20, $375-385$.

233. Blaise, C.; Mazzia, C.; Bischoff, A.; Millon, A.; Ponel, P.; Blight, O. The key role of inter-row vegetation and ants on predation in Mediterranean organic vineyards. Agric. Ecosyst. Environ. 2021, 311, 107327. [CrossRef]

234. Agustí, N.; Shayler, P.S.; Harwood, J.D.; Vaughan, I.P.; Sunderland, K.D.; Symondson, W.O.C. Collembola as alternative prey sustaining spiders in arable ecosystems: Prey detection within predators using molecular markers. Mol. Ecol. 2003, 12, 3467-3475. [CrossRef]

235. Bauer, T. Beetles which use a setal trap to hunt springtails: The hunting strategy and apparatus of Leistus (Coleoptera, Carabidae). Pedobiologia 1985, 28, 275-287.

236. Oelbermann, K.; Langel, R.; Scheu, S. Utilization of prey from the decomposer system by generalist predators of grassland. Oecologia 2008, 155, 605-617. [CrossRef]

237. Lavelle, P.; Bignell, D.; Lepage, M. Soil function in a changing world: The role of invertebrate ecosystem engineers. Eur. J. Soil Biol. 1997, 33, 159-193.

238. Jouquet, P.; Dauber, J.; Lagerlöf, J.; Lavelle, P.; Lepage, M. Soil invertebrates as ecosystem engineers: Intended and accidental effects on soil and feedback loops. App. Soil Ecol. 2006, 32, 153-164. [CrossRef]

239. Ashton, L.A.; Griffiths, H.M.; Parr, C.L.; Evans, T.A.; Didham, R.K.; Hasan, F.; The, Y.A.; Tin, H.S.; Vairappan, C.S.; Eggleton, P. Termites mitigate the effects of drought in tropical rainforest. Science 2019, 363, 174-177. [CrossRef] [PubMed]

240. Shukla, R.K.; Singh, H.; Rastogi, N.; Agarwal, V.M. Impact of abundant Pheidole ant species on soil nutrients in relation to the food biology of the species. App. Soil Ecol. 2013, 71, 15-23. [CrossRef]

241. Cerda, A.; Jurgensen, M.F. The influence of ants on soil and water losses from an orange orchard in eastern Spain. J. Appl. Entomol. 2008, 132, 306-314. [CrossRef]

242. Jouquet, P.; Janeau, J.L.; Pisano, A.; Hai, T.S.; Orange, D.; Minh, L.T.N.; Valentin, C. Influence of earthworms and termites on runoff and erosion in a tropical steep slope fallow in Vietnam: A rainfall simulation experiment. Appl. Soil Ecol. 2012, 61, 161-168. [CrossRef]

243. Evans, T.A.; Dawes, T.Z.; Ward, P.R.; Lo, N. Ants and termites increase crop yield in a dry climate. Nat. Commun. 2011, 2, 262. [CrossRef]

244. Ali, I.G.; Sheridan, G.; French, J.R.J.; Ahmed, B.M. Ecological benefits of termite soil interaction and microbial symbiosis in the soil ecosystem. J. Earth Sci. Geotech. Eng. 2013, 3, 63-85.

245. Ginzburg, O.; Whitford, W.G.; Steinberger, Y. Effects of harvester ant (Messor spp.) activity on soil properties and microbial communities in a Negev Desert ecosystem. Biol. Fertil. Soil. 2008, 45, 165-173. [CrossRef]

246. Issoufou, A.A.; Soumana, I.; Maman, G.; Konate, S.; Mahamane, A. Effects of termites growth on litter decomposition: A modeling approach. Int. J. Recycl. Org. Waste Agric. 2019, 8, S415-S421. [CrossRef]

247. Prosdocimi, M.; Jordán, A.; Tarolli, P.; Keesstra, S.; Novara, A.; Cerdà, A. The immediate effectiveness of barley straw mulch in reducing soil erodibility and surface runoff generation in Mediterranean vineyards. Sci. Total Environ. 2016, 547, 323-330. [CrossRef] 
248. Bertone, M.A.; Green, J.T.; Washburn, S.P.; Poore, M.H.; Watson, D.W. The contribution of tunneling dung beetles to pasture soil nutrition. Forage Grazinglands 2006, 4, 1-12. [CrossRef]

249. Byk, A.; Piętka, J. Dung beetles and their role in the nature. Eduk. Biol. Sr. 2018, 1, 17-26. [CrossRef]

250. Brown, J.; Scholtz, C.H.; Janeau, J.-L.; Grellier, S.; Podwojewski, P. Dung beetles (Coleoptera: Scarabaeidae) can improve soil hydrological properties. Appl. Soil Ecol. 2010, 46, 9-16. [CrossRef]

251. Richardson, A.M.M.; Morton, H.P. Terrestrial amphipods (crustacea, amphipoda, F. Talitridae) and soil respiration. Soil Biol. Biochem. 1986, 18, 197-200. [CrossRef] 